\author{
RESEARCH ARTICLE \\ 10.1029/2018JB017080 \\ Key Points: \\ - We conducted an active-source \\ seismic experiment across the \\ Challenger Deep, revealing a new \\ velocity model of the southernmost \\ Mariana margin \\ - Reduction in crustal velocity was \\ observed in the subducting plate, \\ especially in a near-trench zone, \\ possibly due to porosity changes and \\ fluids; Relatively low upper mantle \\ velocities were interpreted as mantle \\ serpentinization \\ - A low-velocity zone of $~ 15-$ to \\ 20-km-wide was imaged beneath the \\ Southwest Mariana Rift, interpreted \\ as a weak zone of initial rifting
}

Supporting Information:

- Supporting Information S1

Correspondence to:

J. Lin and S. Xia,

jlin@whoi.edu;

shxia@scsio.ac.cn

Citation:

Wan, K., Lin, J., Xia, S., Sun, J., Xu, M., Yang, H., et al. (2019). Deep seismic structure across the southernmost Mariana Trench: Implications for arc rifting and plate hydration. Journal of Geophysical Research: Solid Earth, 124, 4710-4727. https://doi.org/10.1029/ 2018JB017080

Received 22 NOV 2018

Accepted 1 APR 2019

Accepted article online 5 APR 2019

Published online 11 MAY 2019

(C)2019. American Geophysical Union. All Rights Reserved.

\section{Deep Seismic Structure Across the Southernmost Mariana Trench: Implications for Arc Rifting and Plate Hydration}

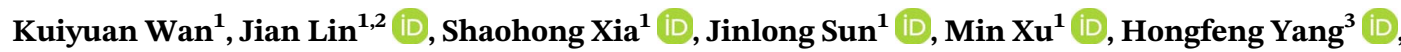 \\ Zhiyuan Zhou ${ }^{1}$, Xin Zeng ${ }^{1}$, Jinghe $\mathrm{Cao}^{1}$, and Huilong $\mathrm{Xu}^{1}$ \\ ${ }^{1}$ Key Laboratory of Ocean and Marginal Sea Geology, South China Sea Institute of Oceanology, Chinese Academy of \\ Sciences, Guangzhou, China, ${ }^{2}$ Department of Geology and Geophysics, Woods Hole Oceanographic Institution, Woods \\ Hole, MA, USA, ${ }^{3}$ Earth System Science Programme, Faculty of Science, The Chinese University of Hong Kong, Shatin, \\ Hong Kong, China
}

\begin{abstract}
The southernmost Mariana margin lacks a mature island arc and thus differs significantly from the central-north Mariana and Izu-Bonin margins. This paper presents a new $P$ wave velocity model of the crust and uppermost mantle structure based on a 349-km-long profile of wide-angle reflection/refraction data. The active source seismic experiment was conducted from the subducting Pacific plate to the overriding Philippine plate, passing through the Challenger Deep. The subducting plate has an average crustal thickness of $\sim 6.0 \mathrm{~km}$ with $\mathrm{Vp}$ of $7.0 \pm 0.2 \mathrm{~km} / \mathrm{s}$ at the base of the crust and low values of only $5.5-6.9 \mathrm{~km} / \mathrm{s}$ near the trench axis. The uppermost mantle of the subducting plate is characterized by low velocities of $7.0-7.3 \mathrm{~km} / \mathrm{s}$. The overriding plate has a maximum crustal thickness of $\sim 18 \mathrm{~km}$ beneath the forearc with $\mathrm{Vp}$ of $\sim 7.4 \mathrm{~km} / \mathrm{s}$ at the crustal bottom and $7.5-7.8 \mathrm{~km} / \mathrm{s}$ in the uppermost mantle. A zone of slight velocity reduction is imaged beneath the Southwest Mariana Rift that is undergoing active rifting. The observed significant velocity reduction in a near-trench crustal zone of $\sim 20-30 \mathrm{~km}$ in the subducting plate is interpreted as a result of faulting-induced porosity changes and fracture-filling fluids. The velocity reduction in the uppermost mantle of both subducting and overriding plates is interpreted as mantle serpentinization with fluid sources from dehydration of the subducting plate and/or fluid penetration along faults.
\end{abstract}

Plain Language Summary The southernmost Mariana margin is a convergence margin that lacks a mature island arc. The trench reaches the deepest point on Earth at the Challenger Deep, the origin of which is still little known. We acquired and analyzed new active source wide-angle reflection/refraction seismic data along a profile across the Challenge Deep, obtaining a new model of crustal and uppermost mantle velocity structure of both the subducting Pacific and overriding Philippine Sea plates. Significant velocity reduction is observed in the crust of the subducting plate, especially in a 20 - to 30-km-wide zone near the trench axis, which is interpreted as a result of faulting-induced porosity changes and fracture-filling fluids. A zone of slight velocity reduction is imaged beneath the tectonically active Southwest Mariana Rift. Significant velocity reduction is also observed in the uppermost mantle of both subducting and overriding plates and is interpreted as a result of mantle serpentinization.

\section{Introduction}

Arc rifting and plate hydration play critical roles in the tectonics, magmatism, water cycling, and earthquake rupture of a subduction system (e.g., Brown \& Ryan, 2011; Horiuchi \& Iwamori, 2016; Suyehiro et al., 1996; Takahashi et al., 2008, 2009; Van Avendonk et al., 2011). The Izu-Bonin-Mariana (IBM) subduction zone is a prominent example of an intraoceanic convergent margin, where the arc has not experienced arc-arc or arccontinental collision, except at the northern end (Figure 1). The IBM has experienced a complex arc rifting history (Ishizuka et al., 2006; Okino et al., 1994; Ribeiro et al., 2013; Takahashi et al., 2008, 2009), and thus is one of the best locations to study arc rifting.

The degree of arc evolution is variable along the IBM subduction system. The Southwest Mariana Rift (SWMR) is located at the southernmost Mariana, which separates the Western Mariana Ridge (WMR) and forearc blocks (Martinez et al., 2018). The SWMR differs from the Mariana Trough (MT) along the central-north Mariana. The MT is a well-developed back-arc basin with crustal thickness of mostly 5-6 km between the Mariana arc (MA) and WMR (Bibee et al., 1980; Takahashi et al., 2008). However, the SWMR has undergone much less opening and is in a stage of tectonic rifting (Martinez et al., 2018). 


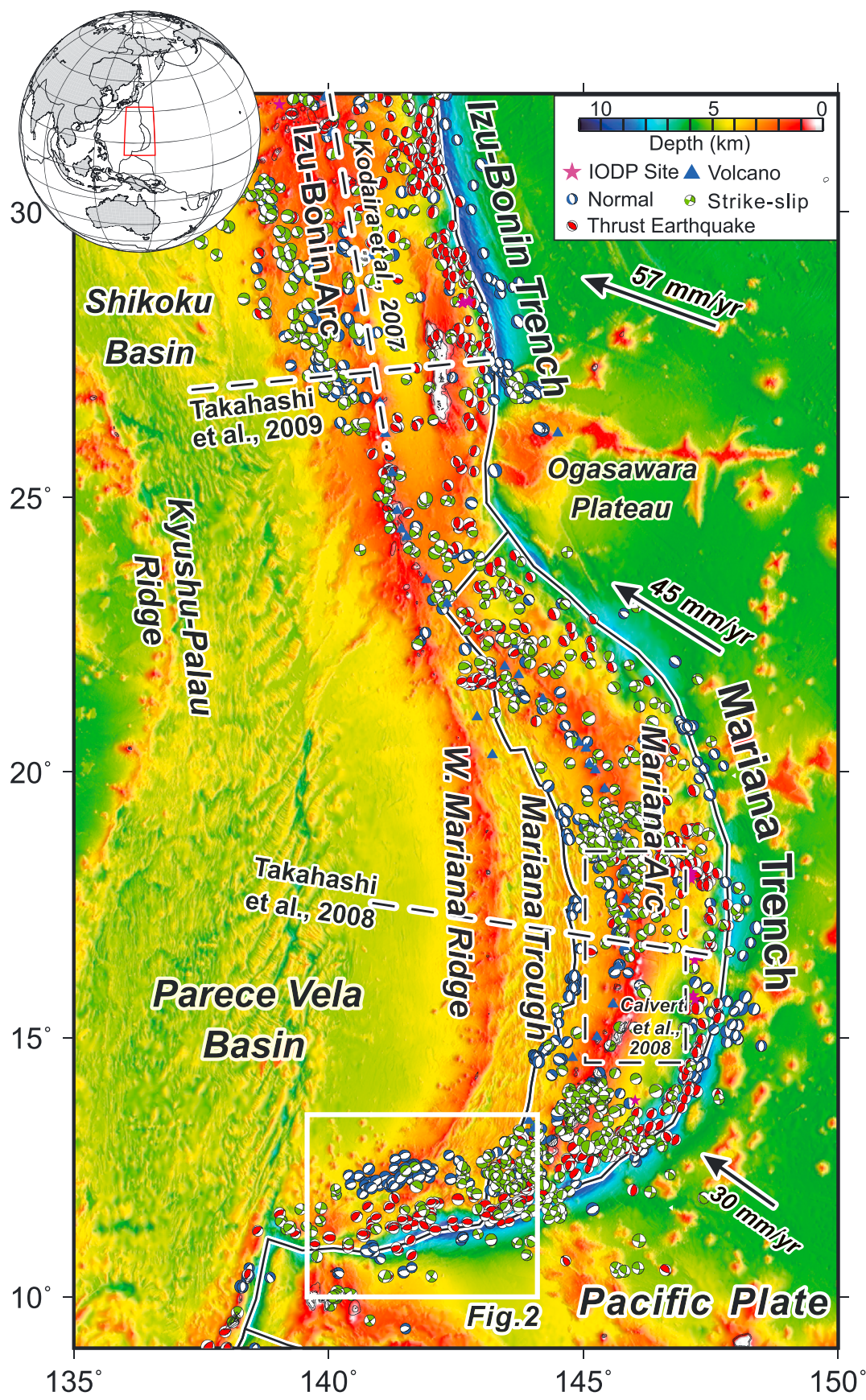

Figure 1. Bathymetry of the Izu-Bonin-Mariana arc-back-arc system showing the locations of earthquakes, volcanoes, and IODP drill sites. White box at the southern end of the Mariana Trench encloses the study area and is enlarged in Figure 2. Earthquake focal mechanisms are from the Global Centroid Moment Tensor project (Dziewonski et al., 1981; Ekström et al., 2012). Dashed black lines denote seismic profiles of Takahashi et al. (2008, 2009) and Kodaira et al. (2007) Dashed rectangle indicates the location of the 3-D survey of Calvert et al. (2008). Solid black lines are the plate boundaries.

The structural differences between the SWMR and MT are complex and still poorly known. This study will provide new constraints on the structure and possible mechanisms for the formation of the SWMR.

Hydration of the crust and upper mantle near trenches has a major impact on the subduction water cycle (e.g., Cai et al., 2018; Shillington, 2018). The hydration process at the IBM system has long been considered to be vigorous based on the prevalence of serpentinite mud volcanoes in the forearc (Suyehiro et al., 1996; Wheat et al., 2008), exposed serpentinized peridotites on seafloor (Ohara et al., 2012; Ohara \& Ishit, 1998), 

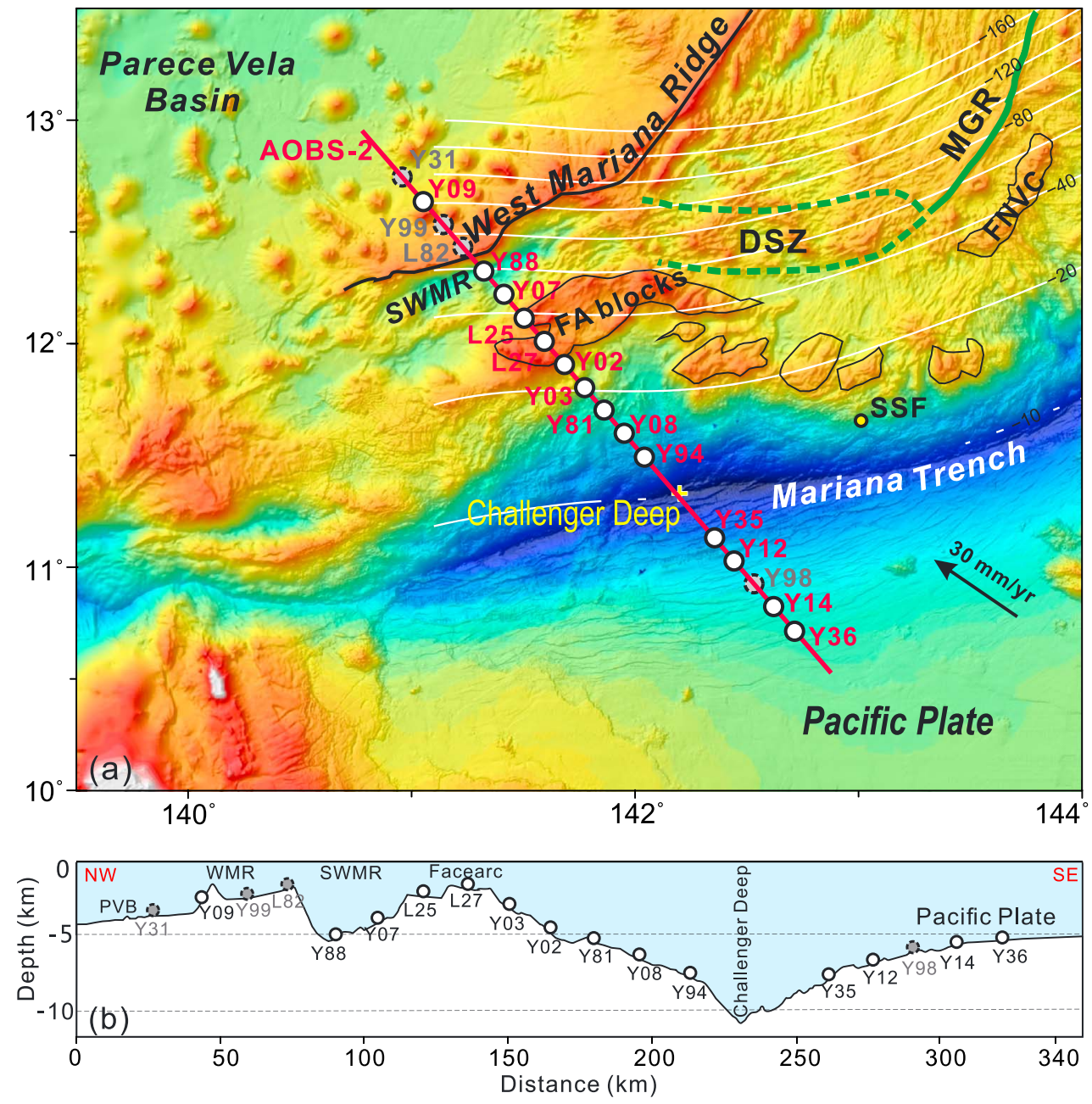

Figure 2. (a) Overview map of the southernmost Mariana showing the location of our wide-angle seismic profile. The slab depth contours (thin white lines) are from Slab 2,0 model of Hayes et al. (2018). White circles denote OBS stations of successful recovery and gray circles represent lost OBSs. The green solid line is the MGR. Locations of the DSZ and the SWMR are as identified by Martinez et al. (2018); SSF from Ohara et al. (2012); FNVC from Brounce et al. (2016); and FA blocks from Martinez et al. (2018). Seafloor depth scale is the same as in Figure 1. (b) Active source OBS stations (white circles) along the seismic profile across the Challenger Deep. FA = forearc; SWMR = Southwest Mariana Rift;

DSZ = diffuse spreading zone; MGR $=$ Malaguana-Gadao Ridge; FNVC $=$ Fina Nagu Volcanic Chain; SSF $=$ Shinkai Seep Field; PVB = Parece Vela basin; WMR = West Mariana Ridge; OBS = ocean bottom seismometer.

reduced seismic velocity anomalies that were interpreted as serpentinized forearc mantle (Barklage et al., 2015; Cai et al., 2018), and geochemical evidence for hydrous arc (Kelley et al., 2010). Recent studies of Cai et al. (2018) of the central Mariana Trench suggested that significantly greater amount of water has entered the Earth than previously thought. Although an outcrop of serpentinized peridotite was observed in the Shinkai Seep Field at about $\sim 100 \mathrm{~km}$ northeast of the Challenger Deep (Ohara et al., 2012, Figure 2), the overall plate hydration process across the southernmost Mariana Trench is still poorly known.

Over the past 20 years, a number of wide-angle seismic experiments, including experiments along five 2-D profiles and on a 3-D grid, have been conducted to constrain the variation in crustal structure of the IBM subduction system (Calvert et al., 2008; Kodaira et al., 2007; Kodaira et al., 2007; Kodaira et al., 2008; Stern et al., 2003; Suyehiro et al., 1996; Takahashi et al., 2007; Takahashi et al., 2008, 2009). However, the existing seismic profiles are mostly limited only to the northern-central IBM system, and little seismic data were available for the southernmost Mariana. In November-December 2016 we carried out an active source seismic experiment across the Challenger Deep and the SWMR, obtaining critical constraints on the crustal and upper mantle velocity structure of the southernmost Mariana. In this paper we present the key results of 
a detailed analysis of the seismic data. The analysis revealed a zone of low velocity and crustal thinning beneath the SWMR, which is interpreted as the result of active rifting. In the subducting Pacific plate, velocity reduction in the crust is observed, especially in a near-trench zone of $\sim 20-30 \mathrm{~km}$, possibly due to faulting-related porosity changes and fracture-filling fluids. Furthermore, relatively low upper mantle velocities are found in both the subducting and overriding plates, interpreted as evidence for mantle serpentinization.

\section{Geological Setting}

The IBM subduction zone is located along the eastern margin of the Philippine Sea plate with the IBM arc began $52 \mathrm{Ma}$ (Ishizuka et al., 2011, 2018). The arc system has experienced back-arc opening twice in its evolution history (Okino et al., 1994; Okino et al., 1998; Stern et al., 2003; Yamazaki \& Stern, 1997). The early arc experienced an initial rifting episode in the Oligocene followed by back-arc spreading, creating the Shikoku basin in the north and the Parece Vela basin in the south (Okino et al., 1994; Taylor, 1992). After this rifting episode, the IBM arcs experienced new episodes of nonsynchronous rifting.

Previous seismic studies (Calvert et al., 2008; Suyehiro et al., 1996; Takahashi et al., 2008, 2009) and highresolution topography (Figure 1) have revealed that the crustal structure is distinctly different between the northern and southern IBM arc system. In the north-central Mariana, the MA was separated from the WMR at about $~ 8 \mathrm{Ma}$, and a secondary seafloor spreading episode commenced 3-4 Ma, creating the MT (Crawford et al., 1981; Fryer, 1995; Stern et al., 2003). The northern Izu-Bonin arc has experienced more arc-rifting than the MA (Takahashi et al., 2007, 2009). The Bonin arc has experienced two episodes of arc rifting, forming two distinctive troughs, that is, the Ogasawara Trough and Nishinoshima Trough. The Ogasawara Trough was created 41-45 Ma (Ishizuka et al., 2006), significantly earlier than the Nishinoshima Trough that was formed after the Pliocene (Higuchi et al., 2007). The current rifting phase of the Izu arc started $~ 2 \mathrm{Ma}$, creating a series of rift basins instead of spreading centers (Taylor, 1992).

The convergence between the Pacific and Philippine Sea plates is approximately orthogonal to the E-W trench in the southernmost Mariana margin, which differs significantly from the mostly N-S trend of the IBM arc (Figure 1; Bird, 2003). In the southernmost Mariana, the trench reaches the deepest point on Earth at the Challenger Deep, which is subjected to the greatest tectonic loading and bending (Zhang et al., 2014, 2018). This region lacks a well-defined arc and is characterized by spatially distributed forearc segments that are separated from the Mariana forearc farther north (Figure 2; Martinez et al., 2018; Ribeiro et al., 2013). The Eocene Mariana forearc block was stretched in the late Neogene to accommodate the opening of the MT, resulting in the Southeast Mariana Forearc Rifts and the separation of the Mariana forearc into the northern and western segments (Ribeiro et al., 2013; Martinez et al., 2018).

\section{Data Acquisition and Processing}

The R/V Shiyan 3 of the South China Sea Institute of Oceanology conducted an active source seismic experiment with an array of ocean bottom seismometers (OBSs) from November to December 2016 in the southernmost Mariana Trench. Eighteen four-component OBSs, comprising one hydrophone and threecomponent geophones, were deployed along the 349-km-long NW-SE profile along both the subducting and overriding plates and across the Challenger Deep; 14 OBS instruments were recovered (Figure 2). We deployed the OBSs at a spacing of $\sim 15 \mathrm{~km}$, expect near the trench where the station spacing is larger due to the excessively deep water. The seismic source, which has characteristic low frequency of 3-15 Hz, consisted of an array of four 1,500 cubic inch airguns that were operated at a pressure of 2000 psi $(13.79 \mathrm{MPa})$. The shot interval was set to $90 \mathrm{~s}$, and a total of 1,572 shots were fired from southeast to northwest along the AOBS-2 profile (Figure 2). The data were recorded at a $10 \mathrm{~ms}$ sampling rate.

The OBS data were processed first by correcting time drifts and position errors. The OBS clock offsets were corrected assuming a linear drift during the data collection period. Relocations of instruments on the seafloor were determined by best-fitting the arrival time of the direct water wave using the Monte Carlo and least-square methods. Next, continuously recorded data were converted to the standard SEG-Y format. The recorded phases were filtered from 3 to $15 \mathrm{~Hz}$ through a standard band-pass Butterworth filter to enhance the signal-to-noise $(\mathrm{S} / \mathrm{N})$ ratios of weak seismic phases; a gain was then applied as a function of the offset to optimize the picking at different offset ranges. Overall, the seismic data are of good quality 
with arrivals on some OBS recorded up to a maximum offset of $140 \mathrm{~km}$. Five recorded sections with identified seismic phases are shown in Figure 3.

\section{Travel Time Picking and Modeling}

We manually selected 8,574 clear refraction arrivals, including intracrustal refracted phases (Pg) and refracted phases in the upper mantle $(\mathrm{Pn})$, as well as 3,076 reflections at the crust-mantle boundary (PmP). These arrivals were mainly picked from the vertical components of most of the OBS instruments together with hydrophone components of OBS-Y02, OBS-Y07, OBS-Y09, OBS-L25, and OBS-L27, which are of higher quality than the corresponding vertical components. We used offset-variable travel time pick errors in model inversion. Picking errors of 50 and 80-100 ms were assigned to near and far offset refraction arrivals, respectively. The PmP arrivals were assigned a picking error of $100 \mathrm{~ms}$.

A joint refraction and reflection travel time inversion method (Korenaga et al., 2000) was utilized to construct a 2-D velocity model along the AOBS-2 profile. The tomographic approach of Korenaga et al. (2000) provides a smooth velocity model constrained by the first arrivals (refracted phases) and the reflection from the crust-mantle boundary. The starting model was generated based on multibeam bathymetry and a 1-D velocity model below the seafloor, which increase from $2.0 \mathrm{~km} / \mathrm{s}$ at the seafloor to $7.0 \mathrm{~km} / \mathrm{s}$ at $30 \mathrm{~km}$ depth. We set the initial Moho to be horizontal at depth of $15 \mathrm{~km}$. After five iterations, the RMS misfit was reduced from the first iteration (initial misfit of $0.675 \mathrm{~s}$ ) to the last iteration (final misfit of $0.112 \mathrm{~s}$ ). For the final model, more than $95 \%$ of the travel-time residuals are smaller than $0.2 \mathrm{~s}$ (Figure S1). We also tested various combinations of vertical and horizontal correlation lengths for velocity nodes as well as the smoothing and damping parameters. For the final model, we used a horizontal correlation length of $2 \mathrm{~km}$ at the top of the model that increases to $8 \mathrm{~km}$ at the bottom. Correspondingly, the vertical correlation length was set to increase from $1 \mathrm{~km}$ at the top of the model to $4 \mathrm{~km}$ at the bottom. The smoothing values for velocity and depth were set to 120 and 4, respectively, while the damping values were set to 4 and 6 for velocity and depth, respectively. The correlation length for the Moho interface is $6 \mathrm{~km}$.

\section{Results}

\subsection{Model Resolution and Uncertainties}

A final velocity model obtained is shown in Figure 4a. The derivative weight sum (Figure 4b) provides information on the linear sensitivity of the inversion. Before we describe the details of the crustal structure, we must first evaluate the reliability of the final tomographic inversion model. The reliability of the velocity model was evaluated using the checkerboard test (Zhao et al., 1992). The size of each anomaly block was 20 (horizontal) $\times 5$ (vertical) or 15 (horizontal) $\times 3 \mathrm{~km}$ (vertical), while a peak anomaly value of $\pm 5 \%$ of the background velocity was imposed (Figure S2). The checkerboard test results show good recovery of the pattern along the most of the profile, especially in the central part (e.g., at distance of 100-200 km), where the ray coverage is excellent.

To determine the uncertainties and robustness of our final velocity model, a Monte Carlo method (Korenaga et al., 2000) was employed. We changed the Moho depth within $\pm 4 \mathrm{~km}$, thereby generating 100 random initial velocity models. A total of 100 final models were acquired, and the RMS values of the first iteration and the last iteration are shown in Figure S3b, revealing that all of the starting models have converged to the preferred final model. Figure S3a depicts the Moho and velocity uncertainties calculated from the 100 final models. In the upper part of the overriding arc crust, the standard deviation uncertainties in velocity are mostly less than $0.03 \mathrm{~km} / \mathrm{s}$, due to the relatively high ray density in the region. In the lower crust and uppermost mantle beneath the overriding plate, uncertainties are greater than $0.03 \mathrm{~km} / \mathrm{s}$ but typically less than $0.06 \mathrm{~km} / \mathrm{s}$. In the northwest of the profile (at distance of $40-90 \mathrm{~km}$ ), uncertainties are mostly greater than $0.06 \mathrm{~km} / \mathrm{s}$. In the oceanic crust of the subducting plate, uncertainties range from 0.03 to $0.09 \mathrm{~km} / \mathrm{s}$. Uncertainties increase up to $0.3 \mathrm{~km} / \mathrm{s}$ at the northwest edge (at distance of 0-40 km) and $0.2 \mathrm{~km} / \mathrm{s}$ at the southeastward edge (at 330-349 km). The uncertainties in the Moho depth of the overriding plate range from 0.4 to $1.0 \mathrm{~km}$, while the average Moho depth uncertainties for the subducting Pacific plate are smaller at $0.3 \mathrm{~km}$. 

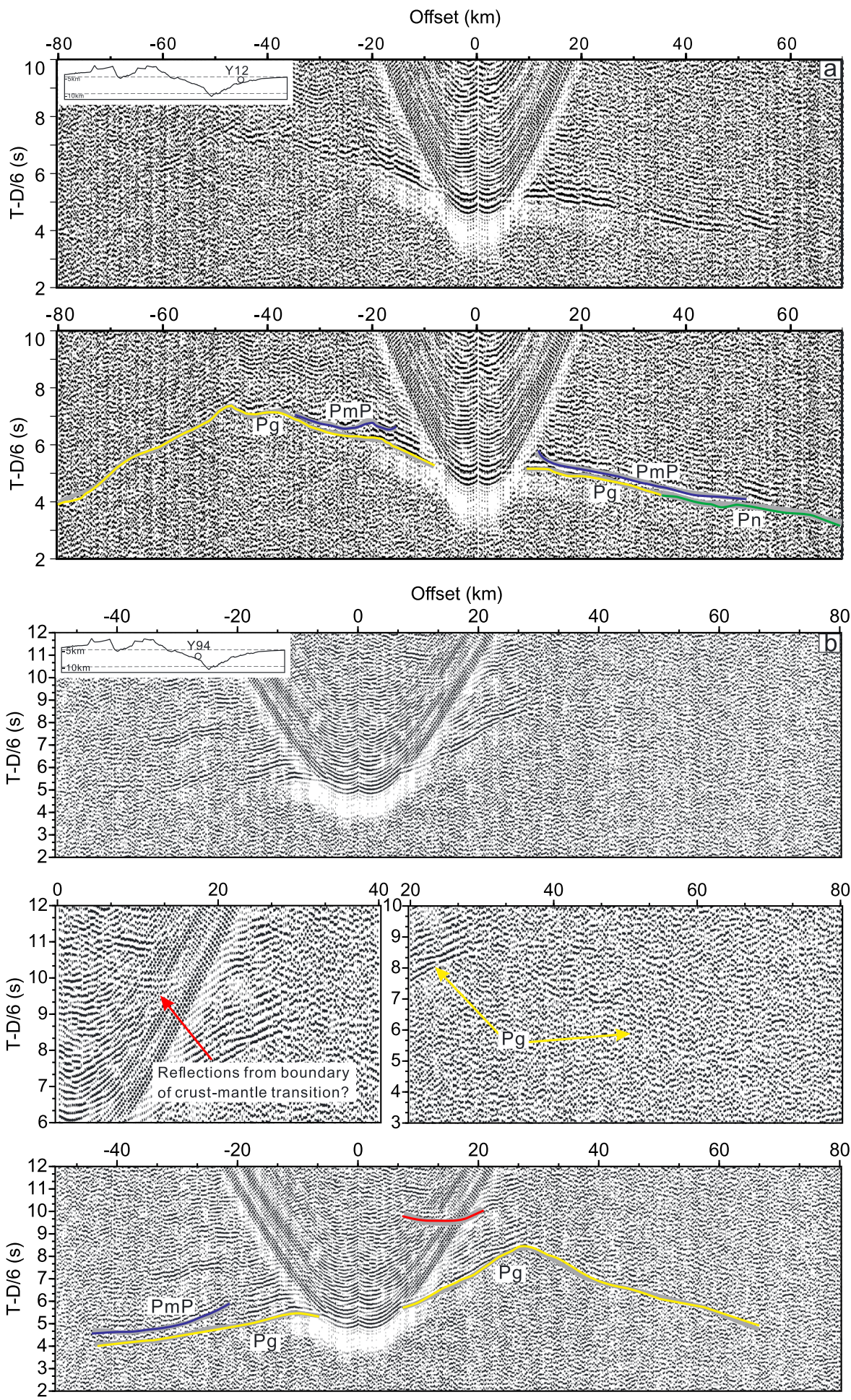

Figure 3. Examples of wide-angle seismic data with the refraction (Pg, yellow; Pn, green) and reflection (PmP, blue) phases. Color and gray lines correspond to the calculated and picked phases, respectively. Corresponding ray paths are in Figure S6. (a and b) Seismic record sections of the vertical components of OBS-Y12 and OBS-Y94, respectively. (c-e) Seismic record sections of the hydrophone components of OBS-Y02, OBS-L27, and OBS-Y08, respectively. The red line in Figure 3b may represent the deep reflections from the lower boundary of a hypothesized crust-mantle transition layer. The recorded sections were filtered by a band-pass filter of 3-15 Hz and are displayed by a reduction velocity of $6 \mathrm{~km} / \mathrm{s}$. The reduced travel time is expressed as T-offset/reduced-velocity. 

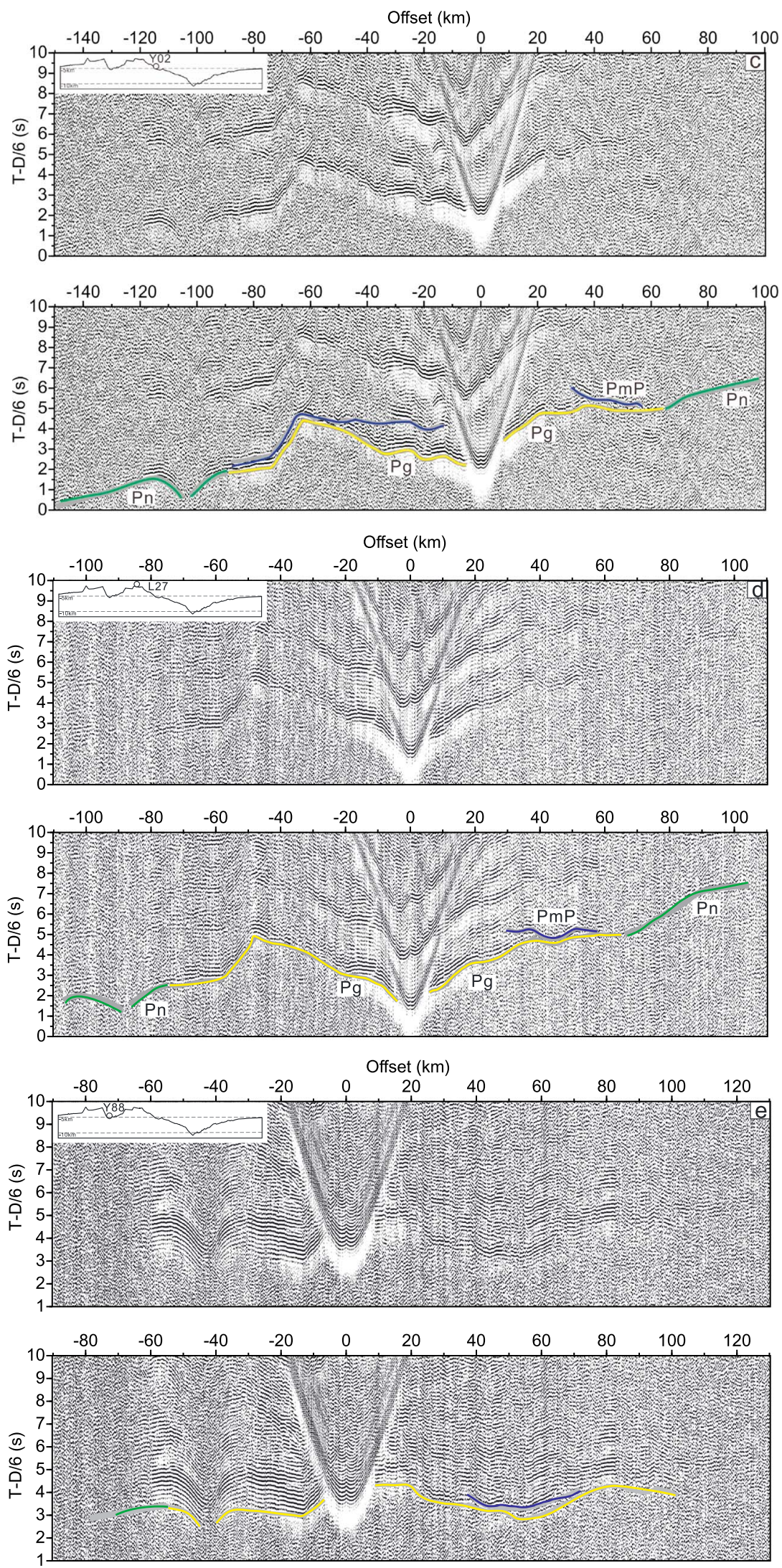

Figure 3. (continued) 

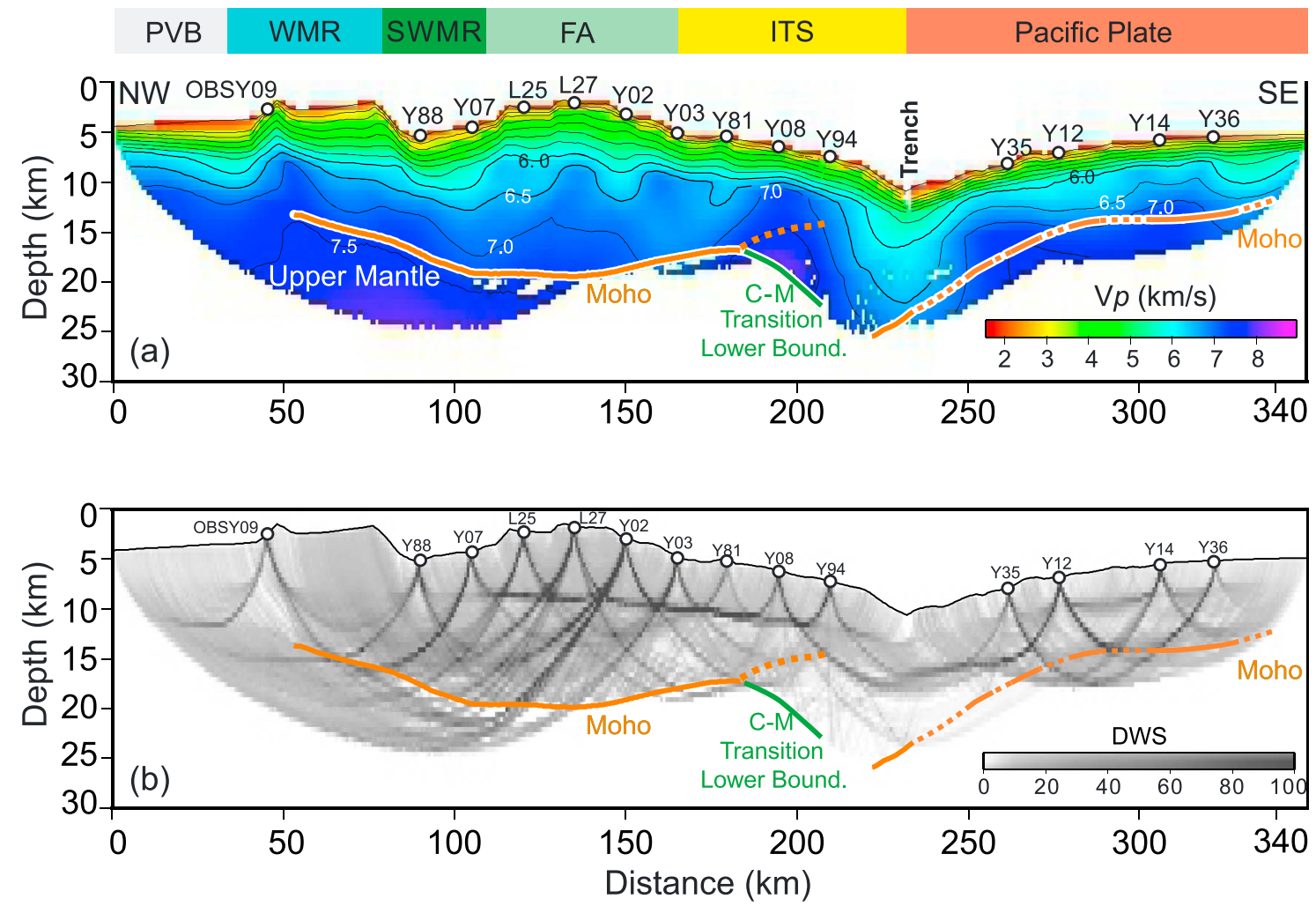

Figure 4. (a) Results of travel-time inversion using the code Tomo2D. Contour interval is $0.5 \mathrm{~km} / \mathrm{s}$. The model is divided into the Pacific plate, ITS, FA, SWMR, WMR, and PVB. Brown solid lines indicate the Moho depths relatively well constrained by PmP arrivals. Dash lines indicate the estimated Moho depths without good PmP constraints. C-M Transition Lower Bound. stands for the lower boundary of a hypothesized crust-mantle transition layer, which is based on the deep reflections in OBS Y94 (Figure 3b). (b) DWS for rays traveling throughout the model. PVB = Parece Vela basin; WMR = West Mariana Ridge;

SWMR = Southwest Mariana Rift; FA = forearc; ITS = inner trench slope; DWS = derivative weight sum.

To minimize the dependence of the final model on the starting models and to reduce the uncertainties, we calculated a model of the velocity difference $\Delta V_{M C-i}$ between the average Monte Carlo model and the average of the starting models (Figure 5a). This approach is effective in illustrating anomalous structures (Delescluse et al., 2015; Wan et al., 2017). We also display $\Delta V_{M C-i}{ }^{-} \sigma$ and $\Delta V_{M C-i}+\sigma$ (Figures 5b and 5c), where $\sigma$ is the Monte Carlo standard deviation. The relatively low velocities below SWMR and in a zone in the subducting plate near the trench axis are visible in all three figures, illustrating that the results of these calculated velocity anomalies are relatively robust and do not depend appreciably on the starting models.

\subsection{Crustal Velocity Anomalies}

In the study region of the southernmost Mariana, there is no obvious magmatic arc as in the centralnorthern Mariana margin; instead, a forearc block lies to the east of the WMR (Figures 2 and 4a). The back-arc spreading center of the MT also did not reach the forearc block (Figure 2). Meanwhile, active tectonic rifting appears to be ongoing at the SWMR, which separates the forearc from the WMR (Figures 2, 4a, and 8). Therefore, we divide the model domain into six regions based on their structural characteristics: the Pacific plate, trench, inner trench slope (ITS), forearc, SWMR, and WMR (Figures 4a and 8). Distinctive velocity gradients were imaged beneath the different regions. Furthermore, these regions show strong lateral heterogeneity in crustal velocity and thickness (Figure 4). In this section, we describe in detail the velocity models in terms of lateral variations in the crust and uppermost mantle.

\subsubsection{Pacific Plate}

In the southeastern part of the seismic profile (at distance of 230-349 km), the Pacific plate has relatively uniform crustal thickness of $6.0 \pm 0.5 \mathrm{~km}$ (Figure $4 \mathrm{a}$ ). On top of the basement is a thin sedimentary cover of 

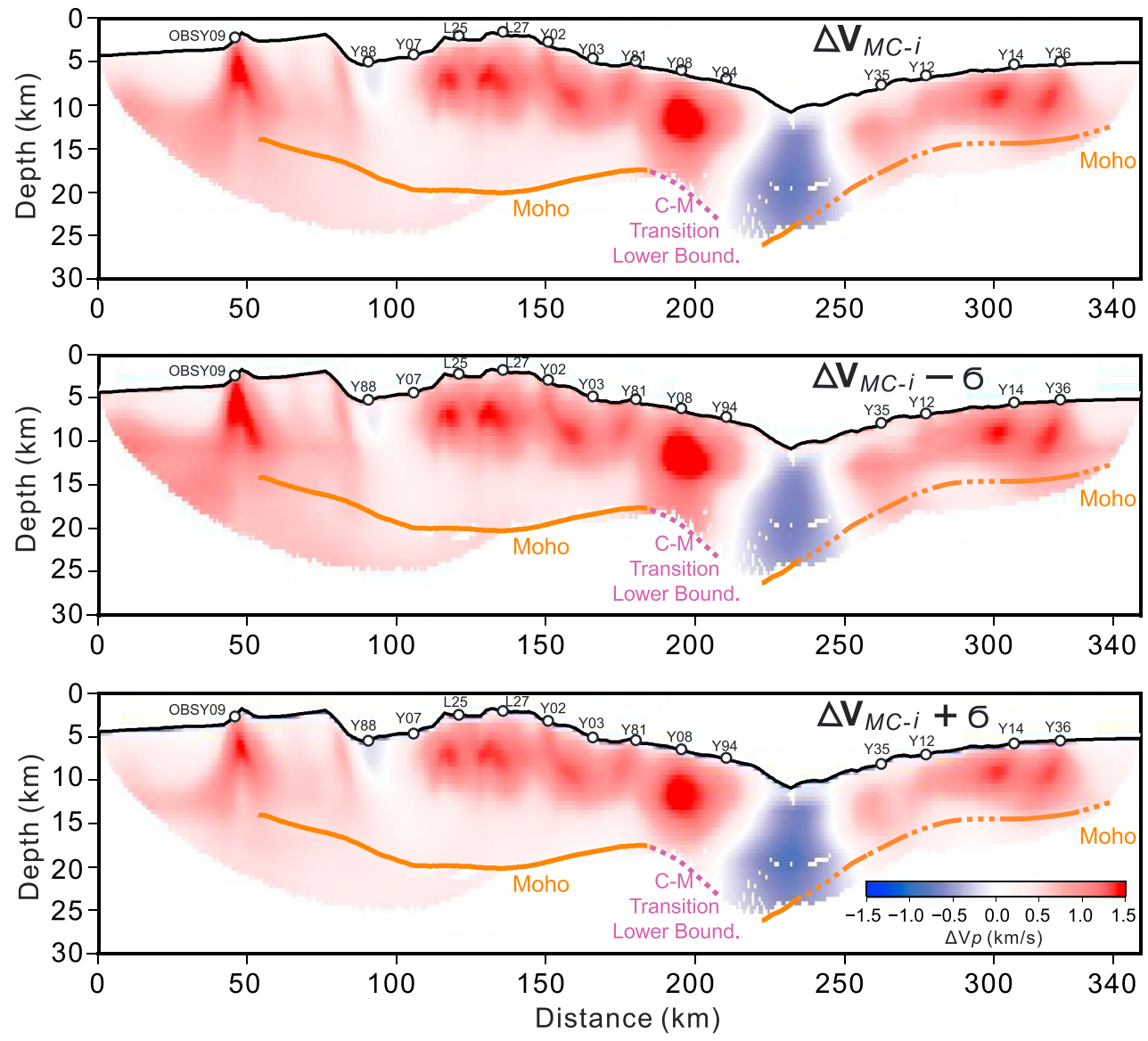

Figure 5. (a) Velocity difference $\Delta V_{M C}$-i between the Monte Carlo average model (Figure 4a) and the average initial model. (b) Velocity difference $\Delta V_{\mathrm{MC}}-\mathrm{i}$ minus the Monte Carlo standard deviation $\sigma$. (c) Velocity difference $\Delta V_{\mathrm{MC}}-\mathrm{i}$ plus the Monte Carlo standard deviation $\sigma$. The low-velocity anomalies beneath the Southwest Mariana Rift (distance of $80-110 \mathrm{~km})$ and near the trench axis $(220-250 \mathrm{~km})$ are observed in all three panels.

$<200 \mathrm{~m}$ thick with velocities of typical pelagic sediments (1.6-2.0 km/s; Ito et al., 1995). The oceanic crust consists of the upper and lower layers with thickness of 2.0 and $3.0-4.0 \mathrm{~km}$, respectively. The velocity range of the upper layer is $3.0-6.0 \mathrm{~km} / \mathrm{s}$ at $250-320 \mathrm{~km}$; local velocity reduction to $5.5 \mathrm{~km} / \mathrm{s}$ is observed near the trench axis (at $230-250 \mathrm{~km}$ ) and to the southeast end of the profile (at $320-349 \mathrm{~km}$ ). However, the velocity structure is not well constrained at the southeast end of the profile.

The crustal structure of the Pacific plate along the profile is characterized by low velocities both in the crust and uppermost mantle. The lower crustal velocity range at distance of $250-320 \mathrm{~km}$ is $6.0-7.1 \mathrm{~km} / \mathrm{s}$. Near the trench axis (at 230-250 km), the velocity range decreases to $5.5-6.8 \mathrm{~km} / \mathrm{s}$, which is significantly lower than the typical oceanic crust (Figure 6b). The uppermost mantle is characterized by extremely low velocities (7.0-7.5 km/s), similar to those found near the Tonga Trench (Contreras-Reyes et al., 2011) but much lower than those of the typical oceanic upper mantle (Figure 6b, Bratt \& Purdy, 1984; White et al., 1992).

5.2.2. ITS

An ITS region of $65-\mathrm{km}$-wide is identified in the southernmost Mariana (at distance of $165-230 \mathrm{~km}$, Figure 4a). The Moho interface is well constrained at $165-180 \mathrm{~km}$ (Figure S6), but cannot be identified at distance of $180-230 \mathrm{~km}$. A reflection boundary was identified in the velocity model, which deepens from $\sim 11 \mathrm{~km}$ at distance of $180 \mathrm{~km}$ to $\sim 17 \mathrm{~km}$ toward the trench axis; this boundary was constrained by deep reflection (Figures $3 \mathrm{~b}$ and S6) phases. Crustal thickness of the ITS region is about $12 \mathrm{~km}$ at distance of $165-180 \mathrm{~km}$; the crust can be divided into the upper and lower layers with thickness of 4.0 and $8.0 \mathrm{~km}$, respectively. The upper crust velocity increases from $3.5 \mathrm{~km} / \mathrm{s}$ near the seafloor to $6.0 \mathrm{~km} / \mathrm{s}$ at $9 \mathrm{~km}$ depth. The thick lower crust layer has velocity range of $6.0-7.0 \mathrm{~km} / \mathrm{s}$ but is dominated by velocities of $6.5-7.0 \mathrm{~km} / \mathrm{s}$. 

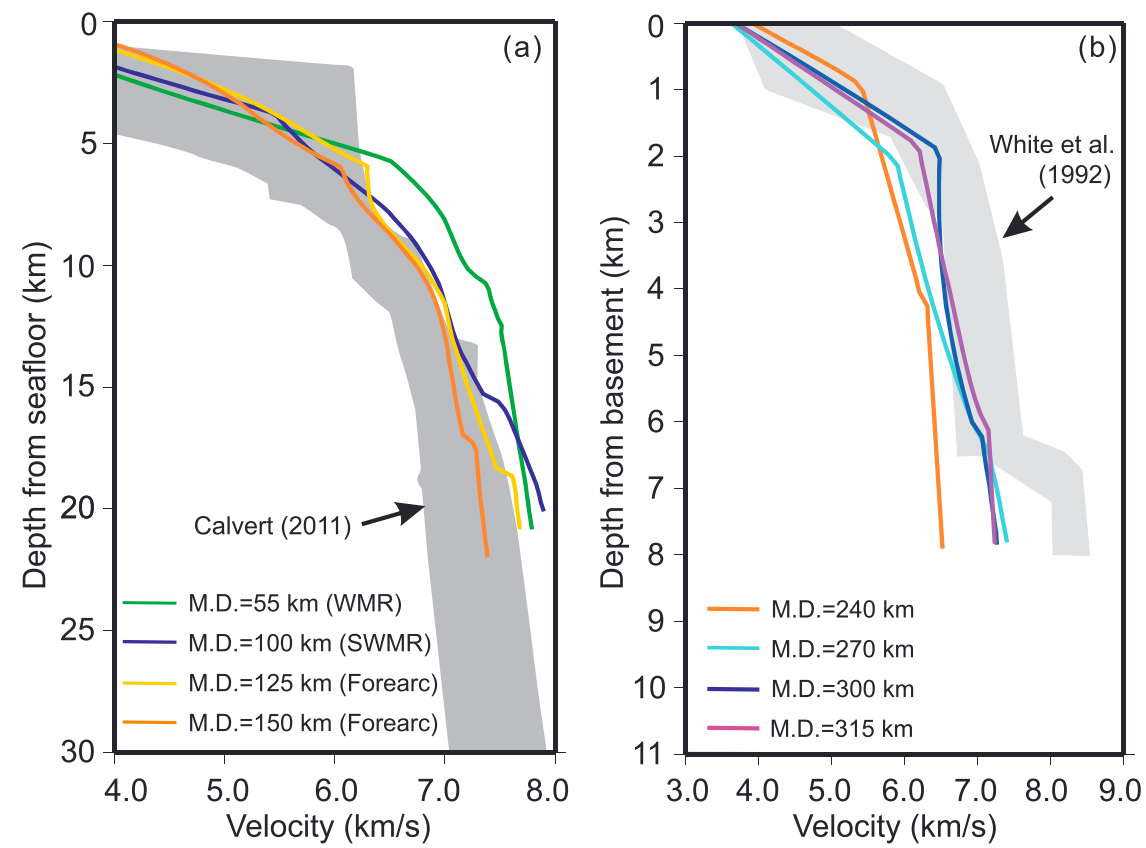

Figure 6. The 1-D velocity-depth profiles extracted from the final model at selected M.D. (a) Comparison with velocity values of other island arcs (Calvert, 2011). The observed velocity profiles of our study area tend to fall outside the velocity envelope of other island arcs. (b) Comparison with velocity values of the mature Pacific oceanic crust (White et al., 1992). WMR = West Mariana Ridge; SWMR = Southwest Mariana Rift; M.D. = model distances.

Considering that serpentinized peridotite outcrops were found on the ITS further to the east of the study region (Ohara et al., 2012; Ohara \& Ishit, 1998), we hypothesize that the observed deep reflector beneath the ITS (distance of 180-210 km) may not be the Moho. Instead, we interpret the deep reflector as the lower boundary of a hypothesized crust-mantle transition layer. Similar transition layer may exist in the Izu margin (e.g., Tatsumi et al., 2008; Takahashi et al., 2009). Meanwhile, the lack of a clear Moho reflector may be related to mantle serpentinization beneath the ITS, resulting in reduced upper mantle velocity of only $6.0-7.7 \mathrm{~km} / \mathrm{s}$ and lesser crust-mantle velocity contrast. Furthermore, no significant accretionary wedge is developed in the ITS, which could be due to either restricted sediment input and/or significant sediment subduction.

\subsubsection{Forearc}

The forearc highland is located at distance of $110-165 \mathrm{~km}$ in our model, $\sim 65 \mathrm{~km}$ away from the Mariana Trench (Figure 4a). The forearc exhibits high topography and relatively deep Moho, corresponding to a maximum crustal thickness of $\sim 18 \mathrm{~km}$. A thin sedimentary layer of $<200 \mathrm{~m}$ thick cover the area and has velocity of $<2.5 \mathrm{~km} / \mathrm{s}$. Underneath the thin sediment are the upper, middle, and lower crustal layers with velocities of 3.5-6.0, 6.0-6.5, and $6.5-7.4 \mathrm{~km} / \mathrm{s}$, respectively. The uppermost mantle has a velocity range of $7.5-7.8 \mathrm{~km} / \mathrm{s}$, which is lower than the normal upper mantle velocity of $\sim 8.0-8.2 \mathrm{~km} / \mathrm{s}$ (Figure 6b, White et al., 1992).

The upper crust has relatively uniform thickness of $\sim 4 \mathrm{~km}$, exhibits a low vertical velocity gradient, and has no significant lateral velocity variation (Figures $5 \mathrm{a}$ and $7 \mathrm{c}$ ). However, the forearc shows markedly lateral variations in the middle and lower crust. The middle crust has a maximum thickness of $\sim 4 \mathrm{~km}$ at distance of $110-125 \mathrm{~km}$, but is only $1 \mathrm{~km}$ thick at distance of $130-140 \mathrm{~km}$, corresponding to the shallowest seafloor. In the eastern part of the forearc (at 140-165 km), the middle crustal layer has a maximum thickness of $\sim 3 \mathrm{~km}$ and nearly pinches out eastward (Figure 7c). The lower crust beneath the forearc has velocities of 6.5-7.4 km/s. The thickness of the lower crust reaches a maximum of $12 \mathrm{~km}$ in the central part of the forearc, where the middle crust is the thinnest.

\subsubsection{SWMR}

The SWMR is a narrow active rift located at profile distance of $80-110 \mathrm{~km}$ between the forearc and WMR (Figures $4 \mathrm{a}$ and $7 \mathrm{c}$ ). A distinct fault scarp of $>3 \mathrm{~km}$ of fault offset is located at the northwestern boundary 

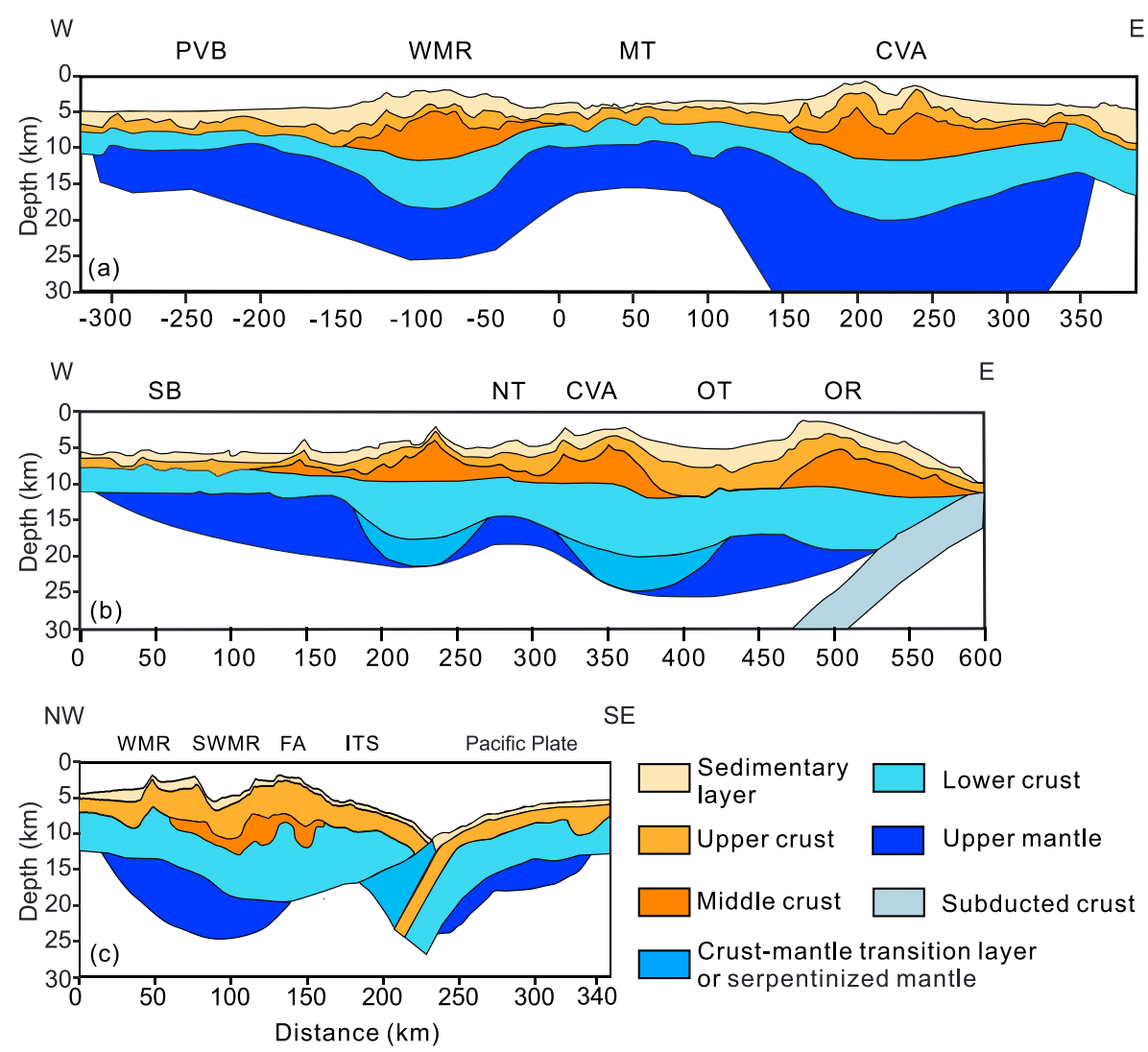

SE

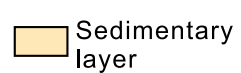

Lower crust

Upper crust

Upper mantle

Middle crust

Subducted crust

Crust-mantle transition layer

or serpentinized mantle

Figure 7. Comparison of velocity structure of the crust and uppermost mantle in three profiles across the Mariana margin (a) A profile across the central Mariana (Takahashi et al., 2008); (b) a profile across the southern Izu (Takahashi et al., 2009); and (c) our profile across the southernmost Mariana. Locations of profiles (a) and (b) are in Figure 1 and profile (c) in Figure 2. $\mathrm{PVB}=$ Parece Vela basin; $\mathrm{WMR}=$ West Mariana Ridge; $\mathrm{MT}=$ Mariana Trough; NT = Nishinoshima Trough; OT = Ogasawara Trough; SWMR = Southwest Mariana Rift; FA = forearc; ITS = inner trench slope.

of the SWMR; the fault offset on the conjugate southeastern rift boundary appears to be less steep. The crustal thickness of the SWMR is $12-14 \mathrm{~km}$, which is slightly thinner than that of the forearc. The sediment layer is relatively thick with a maximum thickness of $\sim 1 \mathrm{~km}$ in the western part of the SWMR and thins eastward. Underlying the sedimentary layer, we identified three crustal layers: the upper $(3.5-6.0 \mathrm{~km} / \mathrm{s})$, middle $(6.0-6.5 \mathrm{~km} / \mathrm{s})$, and lower $(6.5-7.2 \mathrm{~km} / \mathrm{s})$ crust (Figure $7 \mathrm{c})$. The middle crust is relatively thin with thickness of only $1.0-1.5 \mathrm{~km}$. A weak velocity reduction was identified beneath the SWMR (Figure 4a).

\subsubsection{West Mariana Ridge}

The WMR is located west of the SWMR at profile distance of $30-80 \mathrm{~km}$ (Figure 4a); the ridge is a remnant arc that was separated from the MA. The southeastern boundary of the WMR is the distinct fault scarp bounding the SWMR. Underlying a thin sediment layer, the crust can be divided into three layers: Upper (3.5-6.0 km/s), middle $(6.0-6.5 \mathrm{~km} / \mathrm{s})$, and lower $(6.7-7.4 \mathrm{~km} / \mathrm{s})$ crust. The middle and lower crustal layers of the WMR are much thinner than that of the forearc to the southeast (Figure 7c). The entire crustal thickness of the WMR in the study region is $\sim 9-12 \mathrm{~km}$, which is thinner than that of the WMR farther north that has maximum crustal thickness of $17 \mathrm{~km}$ (Takahashi et al., 2008). The velocity-depth profiles of the WMR appear to fall outside of the envelope of typical active island arcs (Figure 6a). The middle crust tapers toward the PVB and is pinched out beneath a seamount between the WMR and PVB (Figures 4a and 7c). The seamount appears to be extinct and is underlain by the upper and lower crust of relatively high velocity. The uppermost mantle beneath the WMR is also characterized by relatively low velocities $(7.5-7.8 \mathrm{~km} / \mathrm{s})$. 


\section{Discussion}

\subsection{Similarities and Differences in Seismic Structure Along the IBM}

The crustal structure in the southernmost Mariana (Figure 7c) is distinctive when comparing with other two cross-sections of the IBM system (Figures 7a and 7b; Calvert et al., 2008; Kodaira et al., 2008; Suyehiro et al., 1996; Takahashi et al., 2007; Takahashi et al., 2009). Along a profile across the central Mariana, conduit-like features of relatively high velocity appear at profile distance of $240 \mathrm{~km}$ and depth of 2-5 km (Figure 7a). Similar features also appear on a profile across the southern Izu at distance of $320 \mathrm{~km}$ and depth of 4-6 km (Figure 7b). Suyehiro et al. (1996) hypothesized that the conduit-like features may be caused by dike swarms that feed monogenetic volcanoes. Such zones of high velocity have been found in the upper crust of both the remnant and current arcs in much of the Izu-Bonin and north-central Mariana, suggesting massive volcanic activity along most of the IBM arc (Suyehiro et al., 1996; Takahashi et al., 2008, 2009). In contrast, in our velocity model of the southernmost Mariana, much of the velocity structure of the upper crust under the forearc is relatively homogeneous without obvious conduit-like features of high velocity (Figure 7c). The lack of such conduit-like features further supports the notion of less arc volcanism in the southernmost Mariana.

The middle arc crust, which is typically associated with velocities of $6.0-6.5 \mathrm{~km} / \mathrm{s}$, has been identified in the IBM arc and interpreted to represent tonalitic crust (Calvert et al., 2008; Suyehiro et al., 1996; Takahashi et al., 2007; Takahashi et al., 2008, 2009). The maximum thickness of the middle arc crust across the Izu, Bonin, and MAs are $\sim 7,6$, and $8 \mathrm{~km}$, respectively (Figures $7 \mathrm{a}$ and $7 \mathrm{~b}$ ). However, in the southernmost Mariana, the middle arc crust has a maximum thickness of only $4 \mathrm{~km}$ (Figure 7c). While the average crustal thickness is similar along the IBM system, the Izu-Bonin and central-northern MAs are much wider than that of the southernmost Mariana; the volume of the arc crust is also smaller at the southernmost Mariana than the rest of the IBM system. Calvert et al. (2008) suggested that a period of $>4 \mathrm{Ma}$ is required to generate a significant volume of middle crust. If the arc has a relatively short (<4 Ma) magmatic history, the materials of 7.0-7.4 km/s velocity would make up a greater proportion of the lower crust. Thus, the relatively thin middle crust of the southernmost Mariana may be related to a relatively short period (2 3 Ma) of magmatism (Calvert et al., 2008; Ishizuka et al., 2006) and/or limited magma supply (Martinez et al., 2018), which could also restricted the degree of crustal differentiation.

The lower crust of the IBM modern arcs has a velocity range of $6.5-7.4 \mathrm{~km} / \mathrm{s}$ and constitutes $\sim 50 \%$ of the entire arc crustal volume (Calvert et al., 2008; Suyehiro et al., 1996; Takahashi et al., 2007; Takahashi et al., 2008, 2009). Our crustal model has similar proportion of the crustal layers with velocity ranges of 6.5-7.0 and 7.0-7.4 km/s (Figure 4a). However, the upper part of the lower crustal layer of the southernmost Mariana (as defined by velocity of $6.5-7.0 \mathrm{~km} / \mathrm{s}$ ) has larger cross-sectional area than in other sections of the IBM, suggesting that the southernmost Mariana might have less dense materials than other arc regions.

Beneath the Izu-Bonin and central-northern Mariana, the mantle velocity values are relatively low (7.4-7.8 km/s; Calvert et al., 2008; Takahashi et al., 2007; Takahashi et al., 2008, 2009). Our velocity model also shows relatively low velocity of $7.5-7.8 \mathrm{~km} / \mathrm{s}$ for the uppermost mantle beneath the WMR and SWMR (Figures 4a, 7c, and 8).

\subsection{Intra-Arc Rifting}

In general, the WMR and MA have similar crustal structure (Calvert et al., 2008; Takahashi et al., 2008). Earlier episodes of arc rifting along the central marina have separated an arc massif into the WMR on the west and MA on the east. In the southernmost Mariana, however, the WMR is much narrower than the northern edifice; the WMR in the study region also has different crustal structure from that of the WMR and MA farther north. The northwestern side of the SWMR is bounded by a distinct steep fault scarp of $>3 \mathrm{~km}$ in relief. A crustal zone of slight velocity reduction was imaged beneath the SWMR (Figure 4a). We infer that the SWMR is a weak zone of arc rifting and is active as indicated by a series of continuous normal faulting events (Figures 1 and 8). This farther supports the inference that the SWMR is still at its young active rifting stage (Martinez et al., 2018).

A model of forearc rifting in the north-central Mariana (Crawford et al., 1981) has suggested that diapirs of MORB-type mantle have pierced through the boninitic arc, eventually leading to the split of the arc. 


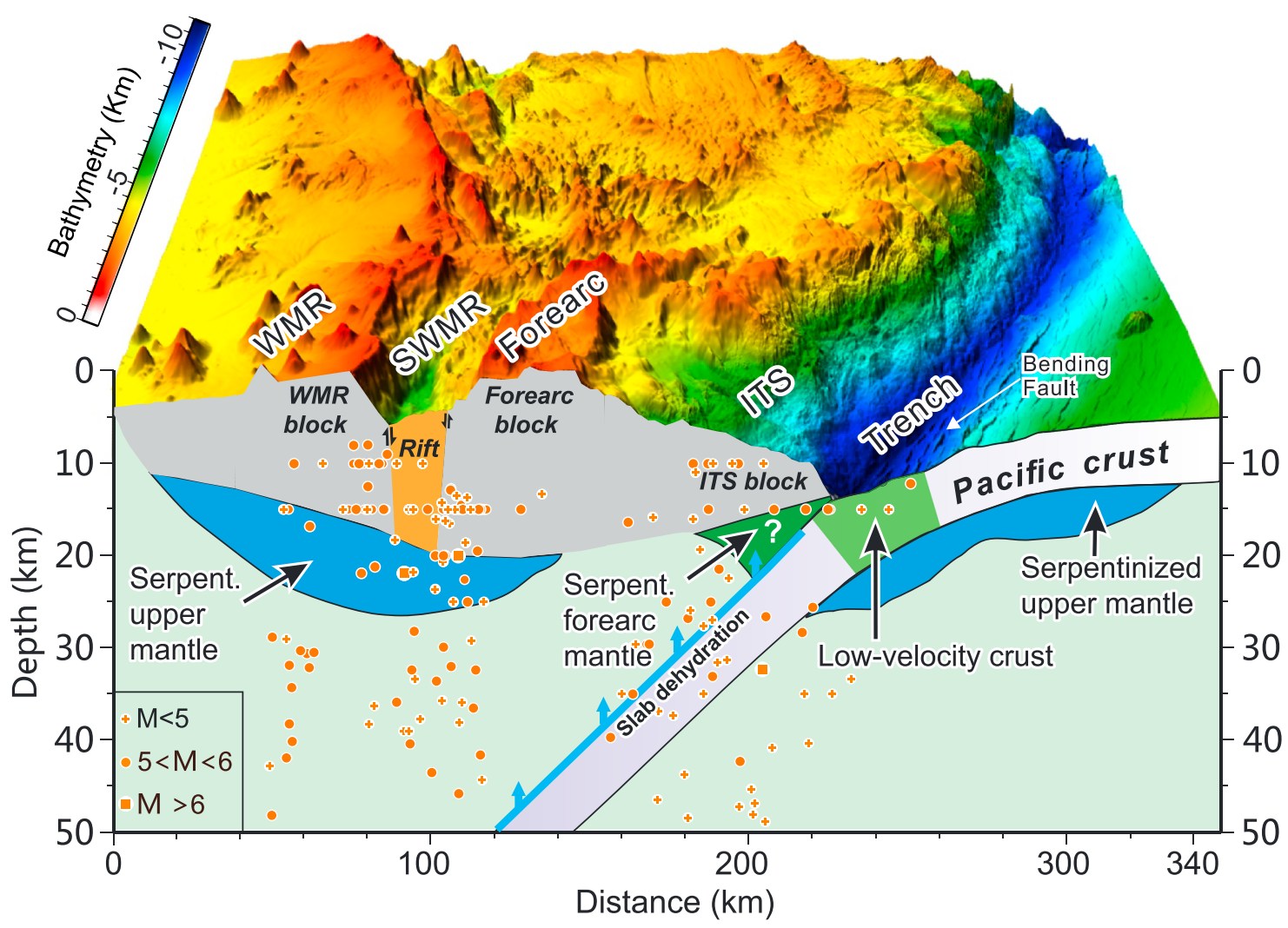

Figure 8. A 3-D map view of the southern Mariana with geological interpretation of the observed velocity model. Orange dots denote epicenters of earthquakes within $30 \mathrm{~km}$ from the seismic profile; the plotted earthquakes include events in 2014-2018 determined by USGS (https://earthquake.usgs.gov/) and events in 1968-2013 determined by ISC (https://www.isc.ac.uk/ehbbulletin/search/catalogue/). The Pacific plate is shown to subduct beneath the Philippine Sea plate with hypothesized slab dehydration. Light green patch: A zone of crustal velocity reduction in the subducting plate, especially near the trench axis. Light blue patches: Zones of reduced velocity in the uppermost mantle under both subducting and overriding plates, interpreted as serpentinized mantle. Dark green patch: Sketch of a hypothesized wedge of crust-mantle transition layer or serpentinized mantle beneath the ITS (distance of 180-220 km). Orange patch: A sketched zone of slight velocity reduction beneath the SWMR. WMR = West Mariana Ridge; SWMR = Southwest Mariana Rift; ITS = inner trench slope.

However, there may be insufficient magma to produce significant volume of diapirs in the southernmost Mariana as reflected by the general lack of volcanic activity. It is noted that the volcanism southward of the MT might be represented by the Fina Nagu Volcanic Chain (Brounce et al., 2016), but there are no noticeable seamounts closer to the WMR and south of a diffused spreading zone in the southernmost Mariana (Figure 2, Martinez et al., 2018).

In a convergent margin, weakening of the upper plate may be caused by the slab-derived water that may change crystal lattice deformation mechanisms (Karato \& Jung, 1998). Arc rifting was hypothesized to occur due to such fluid- and melt-related rheological weakening of the arc lithospherie (Baitsch-Ghirardello et al., 2014). In the southernmost Mariana margin, the slab-derived fluids could occur beneath the forearc and enhance lithospheric melting (Figure 8, Ribeiro et al., 2013), although probably to a much less extent than that of the center-northern Mariana.

We projected USGS and ISC earthquakes at distance of $<30 \mathrm{~km}$ from the profile along the strike of our model, depicting a rough slab shape below $25 \mathrm{~km}$ based on earthquake distribution (Figure 8). The slab dehydration could lead to some degree of mantle melting, providing melts to the arc crust (Kersting et al., 1996; Kimura \& Yoshida, 2006). However, the WMR is located at significant distance away from the trench axis and thus the effects of rising fluids may be relatively weak due to slab rollback and relatively steep subduction angle (Baitsch-Ghirardello et al., 2014; Martinez et al., 2018). Furthermore, Schmidt and Poli (1998) suggested that water release from the slab gradually decreases farther from the trench axis, implying that the forearc and ITS block might be more susceptible to melting than the WMR. Consequently, the rheological properties of the WMR, forearc, and ITS might also be different (Figure 8). 

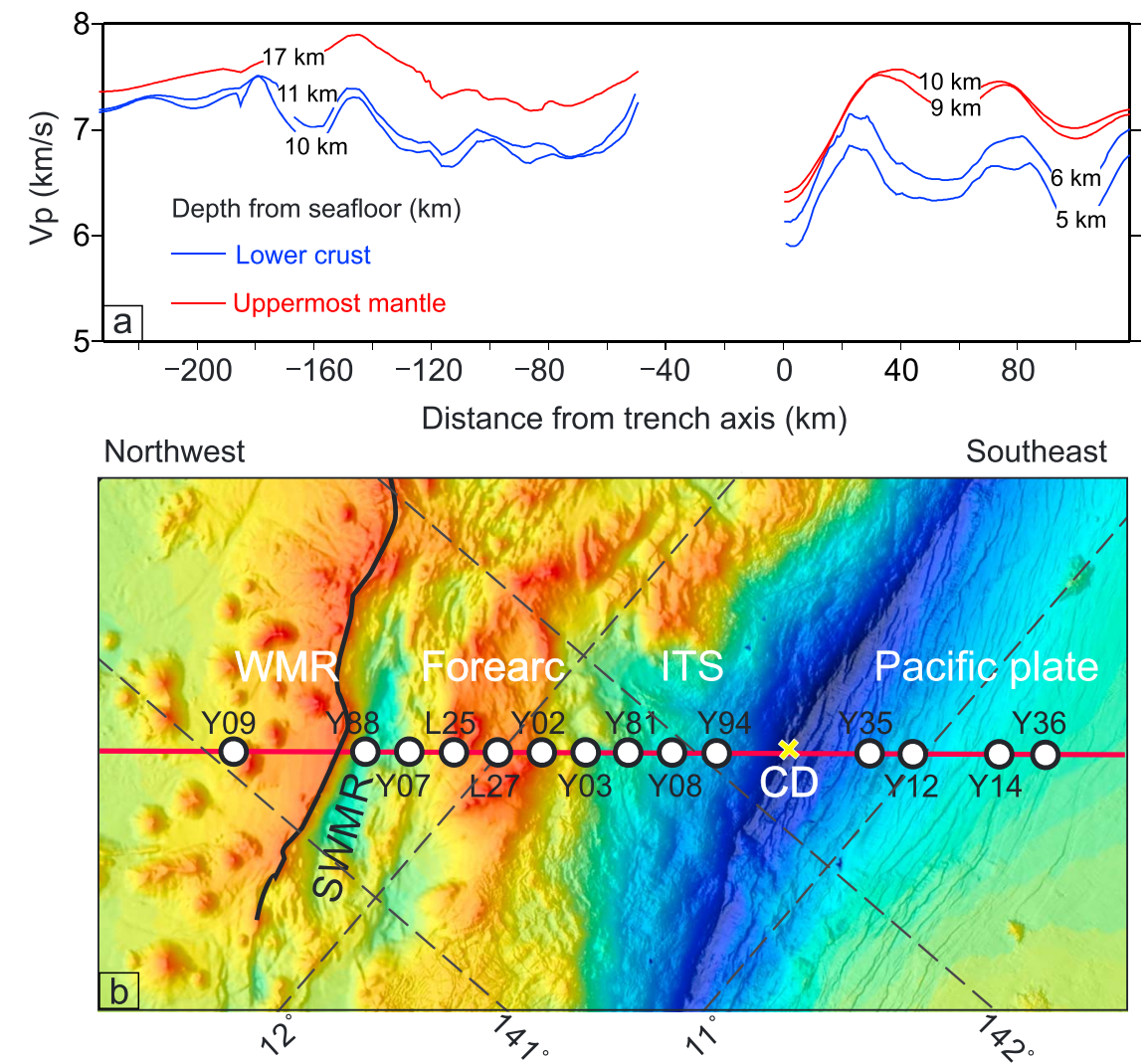

Figure 9. Profiles of lateral velocity variations extracted from our velocity model (Figure 4a) and sampled at selected constant depths from the seafloor. (a) Left: Velocities at depths of 10 and $11 \mathrm{~km}$ (lower crust, blue lines) and $17 \mathrm{~km}$ (uppermost mantle, red line) from the seafloor under the overriding plate. Right: Velocities at depths of $5.0 \mathrm{~km}$ (lower crust, blue line), $6.0 \mathrm{~km}$ (crust-mantle transition depth, blue line), and 9 and $10 \mathrm{~km}$ (uppermost mantle, red lines) under the subducting plate. (b) Bathymetry map showing the southernmost Mariana, the seismic reflection/refraction profile (red line), and stations of successful ocean bottom seismometer instrument recovery (white circles). Map color scale is the same as in Figure 1. CD = Challenger Deep; WMR = West Mariana Ridge; SWMR = Southwest Mariana Rift; ITS $=$ inner trench slope.

\subsection{Plate Hydration}

\subsubsection{Hydration in Subducting Slab}

Velocity reduction in the crust and uppermost mantle of a subducting plate has been observed in regions of significant flexural bending (e.g., Ivandic et al., 2008; Van Avendonk et al., 2011; Fujie et al., 2013, 2018; Shillington et al., 2015). It has been proposed that the velocity reduction is related to bending-induced normal faults, which generate fluid conduits in the crust and facilitate serpentinization of the uppermost mantle (e.g., Cai et al., 2018; Emry et al., 2014; Ranero et al., 2003; Zhou \& Lin, 2018).

Our velocity model of the subducting plate shows profound velocity reduction in the crust and uppermost mantle near the trench axis (Figures $4 \mathrm{a}$ and 5). The velocity of the lower crust (e.g., at depths of 5 and $6 \mathrm{~km}$ below seafloor) shows a marked reduction toward the trench axis at profile distance of 0-20 km (Figure 9a). Furthermore, we acquired the crustal velocity perturbation relative to the average background value of a given depth (Figure 10). The depth-averaged velocity perturbation reached a maximum reduction of $0.8 \mathrm{~km} / \mathrm{s}$ near the trench axis beneath the subducting plate (Figure 10a). Thus, we infer that crustal faults and fluids increase toward the trench axis, resulting in greater velocity reduction.

The studies of Ivandic et al. (2008) and Fujie et al. (2013) suggested that the number of normal faults and crustal water content might increase toward the trench axis over distance of tens of kilometers (Fujie et al., 2018). Zhou et al. (2015) and Zhou and Lin (2018) found that the fault density in the subducting plate at the southernmost Mariana increases trenchward over a distance of $80 \mathrm{~km}$, reached a peak value at $\sim 20 \mathrm{~km}$ from the trench axis; the calculated average fault density is $\sim 1.3$ faults every $5 \mathrm{~km}$. It has been proposed that a 


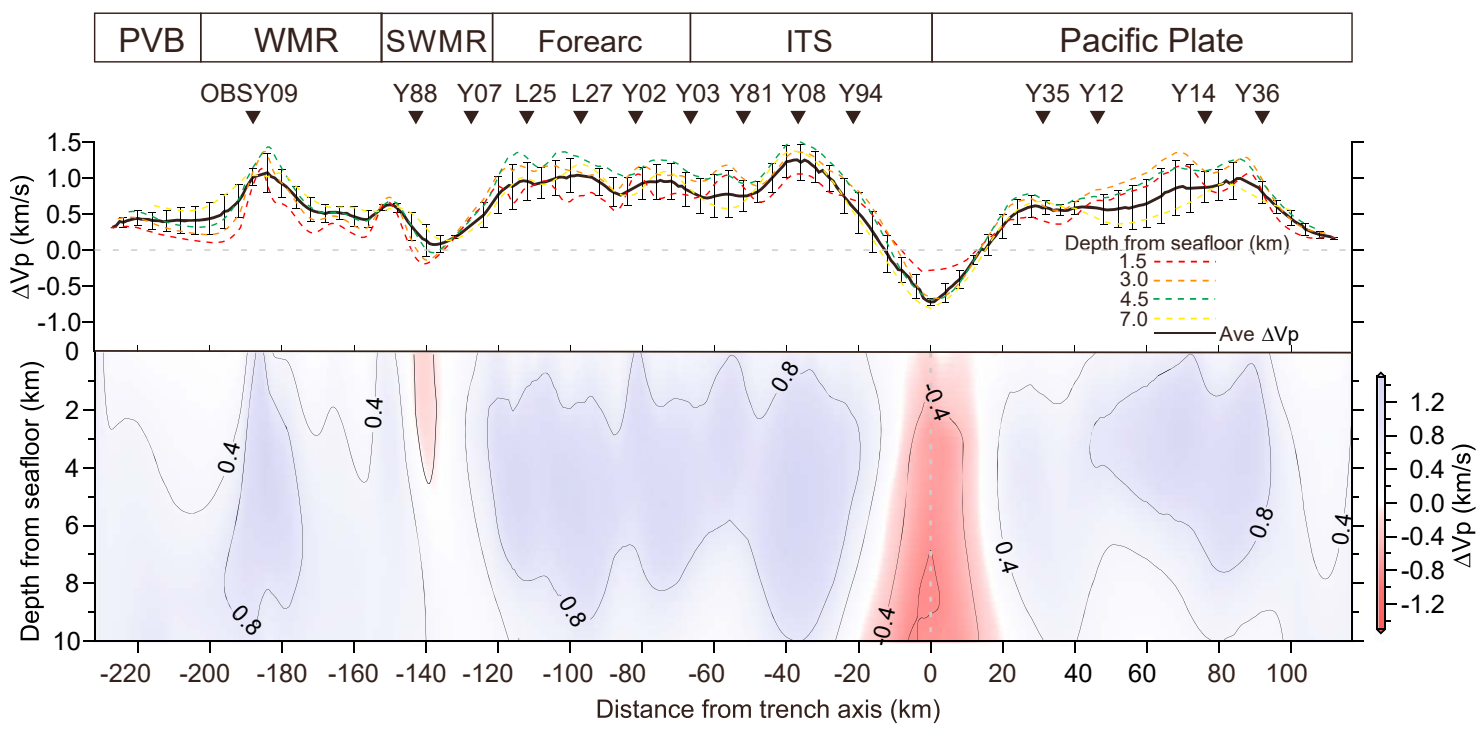

Figure 10. (top) Extracted profiles at selected depths showing velocity perturbation within the crust and uppermost mantle after subtracting the average 1-D velocity at each depth. Color dashed lines show velocity anomalies at depths of 1.5, 3.0, 4.5, and $7.0 \mathrm{~km}$ from the seafloor. Solid black line shows the velocity anomalies averaged over the top $7 \mathrm{~km}$ of the velocity model. (bottom) Cross-section showing velocity perturbation in the top $10 \mathrm{~km}$ of the velocity model after subtracting the average 1-D velocity at each depth. PVB = Parece Vela basin; WMR = West Mariana Ridge; SWMR = Southwest Mariana Rift; ITS = inner trench slope.

few percent increase in fracture porosity may reduce crustal velocity appreciably (Ivandic et al., 2008; Peacock et al., 2011). Thus, we interpret the observed reduction in crustal velocity as the result of faulting-related porosity changes and fracture-filling fluids.

The observed low $\mathrm{Vp}$ in the uppermost mantle of the subducting plate may reflect serpentinization. For example, at depths of 9 and $10 \mathrm{~km}$ below the seafloor, the mantle velocity has low values of 7.0-7.5 km/s at distance of 30-90 km (Figure 9a) and only $6.8-7.0 \mathrm{~km} / \mathrm{s}$ close to the trench axis at distance of 0-20 km. These values are much lower than the typical upper mantle velocities of $8.0-8.2 \mathrm{~km} / \mathrm{s}$ for oceanic crust (Figure 6b, White et al., 1992).

Under isotropic conditions, a commonly used relationship links the Vp and serpentinization as $\mathrm{Vp}=8.0$ $3.1 \Phi$ (Grevemeyer et al., 2018), where $\Phi$ is the amount of serpentinization. The observed Vp ranges of 7.0-7.5 and $6.8-7.0 \mathrm{~km} / \mathrm{s}$ would yield $\sim 16-32 \%$ and $32-38 \%$ of serpentinization, respectively. Such inferred ranges of serpentinization are higher than that estimated for the Nicaragua and Costa Rica (Ivandic et al., 2008, 2010; Van Avendonk et al., 2011) and Kuril and Japan (Fujie et al., 2018) margins. Furthermore, the inferred degree of serpentinization near the trench axis is distinctly greater than the sections farther away from the trench axis.

\subsubsection{Hydration in Overriding Plate}

It has been proposed that a low-velocity wedge of serpentinized mantle might exist beneath the forearc because of slab dehydration (e.g., Hyndman \& Peacock, 2003; Kimura et al., 2009; Peacock et al., 2011; Xia et al., 2008). In the overriding plate of our study region, we have also identified zones of lower than normal velocity in the uppermost mantle. For example, beneath the ITS (at distance of 165-220 km), a wedge of relatively low velocity $(6.0-7.7 \mathrm{~km} / \mathrm{s})$ was found, which is interpreted as a crust-mantle transition layer or serpentinized mantle (Figures $4 \mathrm{a}$ and $7 \mathrm{c}$ ).

The uppermost mantle velocity is also relatively low $(7.5-7.8 \mathrm{~km} / \mathrm{s}$ ) under the forearc (distance of 110$165 \mathrm{~km})$, SWMR (80-110 km), and WMR (30-80 km, Figures 4a and 9a). These velocity values are lower than the typical upper mantle velocities of $8.0-8.2 \mathrm{~km} / \mathrm{s}$ (Figure $6 \mathrm{~b}$, White et al., 1992) and we interpret them as evidence for serpentinized mantle (Figures $7 \mathrm{c}$ and 8 ). It is generally understood that slab-derived fluids could migrate upward to the mantle to generate hydrous minerals and contribute to mantle serpentinization (e.g., Reymer \& Schubert, 1984; Manning, 1995; Suyehiro et al., 1996; Plank \& Langmuir, 1998; Hyndman \& Peacock, 2003; Mottl et al., 2003). Future studies should further investigate the distribution of serpentinized mantle in the southernmost Mariana. 


\section{Conclusions}

We conducted an active-source reflection/refraction seismic experiment along a 349-km-long profile across the Challenger Deep, obtaining a new velocity model of the southernmost Mariana margin that reveals the following key features:

1. The average crustal thickness of the subducting Pacific plate is $\sim 6 \mathrm{~km}$, while the maximum crustal thickness of the overriding Philippine Sea plate is $\sim 18 \mathrm{~km}$.

2. On the subducting plate, crustal velocity is systematically reduced, especially in a 20- to 30-km-wide zone near the trench axis. The observed crustal velocity reduction is interpreted as a result of faulting-induced porosity changes and fracture-filling fluids.

3. Relatively low upper mantle velocities are observed in both subducting plate $(7.0-7.5 \mathrm{~km} / \mathrm{s})$ and overriding plate $(7.5-7.8 \mathrm{~km} / \mathrm{s})$, which is interpreted as a result of mantle serpentinization.

4. A 15- to 20-km-wide zone of low velocity is imaged beneath the SWMR and is interpreted as a zone of initial rifting.

\section{Acknowledgments}

Data acquisition and sample collections were supported by the Mariana Trench Initiative of the Chinese Academy of Sciences (CAS). We are grateful to the science parties and crews of R/V Shiyan 3 of the South China Sea Institute of Oceanology, CAS, for contributions to data acquisition. Constructive reviews by Robert Stern, Martha Savage, and anonymous reviewers significantly improved the manuscript. We thank Gaohua Zhu, Fan Zhang, Chunfeng Li, Zhen Sun, Zhi Wang, and Minghui Zhao for helpful discussion. The bathymetric maps were plotted using GMT (Wessel \& Smith, 1995). Digital files of the velocity models and selected raw data are deposited and accessible online (at https://pan.baidu.com/s/ 1AbDJOgLZhYn1C-3sg7S9Xw). This work was supported by the Strategic Priority Program of CAS (XDA13010101), CAS (Y4SL021001, QYZDY-SSW-DQC005, and 133244KYSB20180029), Key Laboratory of Ocean and Marginal Sea Geology, CAS (OMG18-03), National Natural Science Foundation of China (41890813, 41676042, U1701641, 91628301, 41576041, and U1606401), and HKSAR Research Grant Council grants (14313816)

\section{References}

Baitsch-Ghirardello, B., Gerya, T. V., \& Burg, J. P. (2014). Geodynamic regimes of intra-oceanic subduction: Implications for arc extension vs. shortening processes. Gondwana Research, 25(2), 546-560. https://doi.org/10.1016/j.gr.2012.11.003

Barklage, M., Wiens, D. A., Conder, J. A., Pozgay, S., Shiobara, H., \& Sugioka, H. (2015). PandSvelocity tomography of the Mariana subduction system from a combined land-sea seismic deployment. Geochemistry Geophysics Geosystems, 16(3), 681-704. https://doi.org/ $10.1002 / 2014 G C 005627$

Bibee, L. D., Shor, G. G. Jr., \& Lu, R. S. (1980). Inter-arc spreading in the Mariana Trough. Marine Geology, 35(1-3), 183-197. https://doi.org/ $10.1016 / 0025-3227(80) 90030-4$

Bird, P. (2003). An updated digital model of plate boundaries. Geochemistry Geophysics Geosystems, 4(3), 1027. https://doi.org/10.1029/ 2001GC000252

Bratt, S. R., \& Purdy, G. M. (1984). Structure and variability of oceanic crust on the flanks of the East Pacific Rise between $11^{\circ}$ and $13^{\circ} \mathrm{N}$ Journal of Geophysical Research, 89(B7), 6111-6125. https://doi.org/10.1029/JB089iB07p06111

Brounce, M., Kelley, K. A., Stern, R., Martinez, F., \& Cottrell, E. (2016). The Fina Nagu volcanic complex: Unusual submarine arc volcanism in the rapidly deforming southern Mariana margin. Geochemistry Geophysics Geosystems, 17, 4078-4091. https://doi.org/10.1002/ 2016GC006457

Brown, D., \& Ryan, P. D. (2011). Arc-Continent Collision. Berlin: Springer.

Cai, C., Wiens, D. A., Shen, W., \& Eimer, M. (2018). Water input into the Mariana subduction zone estimated from ocean-bottom seismic data. Nature, 563(7731), 389-392. https://doi.org/10.1038/s41586-018-0655-4

Calvert, A. (2011). The seismic structure of island arc crust. In D. Brown, \& P. D. Ryan (Eds.), Arc-continent collision (pp. 87-119). Berlin Springer. https://doi.org/10.1007/978-3-540-88558-0_4

Calvert, A. J., Klemperer, S. L., Takahashi, N., \& Kerr, B. C. (2008). Three-dimensional crustal structure of the Mariana island arc from seismic tomography. Journal of Geophysical Research, 113, B01406. https://doi.org/10.1029/2007JB004939

Contreras-Reyes, E., Ingo, G., Watts, A. B., Flueh, E. R., Christine, P., Stefan, M., \& Cord, P. (2011). Deep seismic structure of the Tonga subduction zone: Implications for mantle hydration, tectonic erosion, and arc magmatism. Journal of Geophysical Research, $116, \mathrm{~B} 10103$. https://doi.org/10.1029/2011JB008434

Crawford, A. J., Beccaluva, L., \& Serri, G. (1981). Tectono-magmatic evolution of the West Philippine-Mariana region and the origin of boninites. Earth and Planetary Science Letters, 54(2), 346-356. https://doi.org/10.1016/0012-821X(81)90016-9, https://doi.org/10.1016/ 0012-821X(81)90016-9

Delescluse, M., Funck, T., Dehler, S. A., Louden, K. E., \& Watremez, L. (2015). The oceanic crustal structure at the extinct, slow to ultraslow Labrador Sea spreading center. Journal of Geophysical Research: Solid Earth, 120, 5249-5272. https://doi.org/10.1002/ 2014JB011739

Dziewonski, A. M., Chou, T.-A., \& Woodhouse, J. H. (1981). Determination of earthquake source parameters from waveform data for studies of global and regional seismicity. Journal of Geophysical Research, 86(B4), 2825-2852. https://doi.org/10.1029/JB086iB04p02825

Ekström, G., Nettles, M., \& Dziewonski, A. M. (2012). The global CMT project 2004-2010: Centroid-moment tensors for 13,017 earthquakes. Physics of the Earth and Planetary Interiors, 200-201, 1-9. https://doi.org/10.1016/j.pepi.2012.04.002

Emry, E. L., Wiens, D. A., \& Garcia-Castellanos, D. (2014). Faulting within the Pacific plate at the Mariana Trench: Implications for plate interface coupling and subduction of hydrous minerals. Journal of Geophysical Research: Solid Earth, 119, 3076-3095. https://doi.org/ 10.1002/2013JB010718

Fryer, P. (1995). Geology of the Mariana Trough. In B. Taylor (Ed.), Backarc basins: Tectonics and magmatism, (pp. 237-279). Berlin: Springer. https://doi.org/10.1007/978-1-4615-1843-3_6

Fujie, G., Kodaira, S., Yamamoto, Y., Takahashi, T., Miura, S., \& Yamada, T. (2018). Controlling factor of incoming plate hydration at the north-western Pacific margin. Nature Communications, 9(1), 3844. https://doi.org/10.1038/s41467-018-06320-Z

Fujie, G., Kodaira, S., Yamashita, M., Sato, T., Takahashi, T., \& Takahashi, N. (2013). Systematic changes in the incoming plate structure at the Kuril trench. Geophysical Research Letters, 40, 88-93. https://doi.org/10.1029/2012GL054340

Grevemeyer, I., Ranero, C. R., \& Ivandic, M. (2018). Structure of oceanic crust and serpentinization at subduction trenches. Geosphere, 14(2), 395-418. https://doi.org/10.1130/GES01537.1

Hayes, G. P., Moore, G. L., Portner, D. E., Hearne, M., Flamme, H., Furtney, M., \& Smoczyk, G. M. (2018). Slab2, a comprehensive subduction zone geometry model. Science, 362(6410), 58-61. https://doi.org/10.1126/science.aat4723

Higuchi, Y., Yanagimoto, Y., Hoshi, K., Unou, S., Akiba, F., Tonoike, K., \& Koda, K. (2007). Cenozoic stratigraphy and sedimentation history of the northern Philippine Sea based on multichannel seismic reflection data. Island Arc, 16(3), 374-393. https://doi.org/10.1111/ j.1440-1738.2007.00588.x 
Horiuchi, S. S., \& Iwamori, H. (2016). A consistent model for fluid distribution, viscosity distribution, and flow-thermal structure in subduction zone. Journal of Geophysical Research: Solid Earth, 121, 3238-3260. https://doi.org/10.1002/2015JB012384

Hyndman, R., \& Peacock, S. (2003). Serpentinization of the forearc mantle. Earth and Planetary Science Letters, 212(3-4), 417-432. https:// doi.org/10.1016/S0012-821X(03)00263-2

Ishizuka, O., Hickey-Vargas, R., Arculus, R. J., Yogodzinski, G. M., Savov, I. P., Kusano, Y., et al. (2018). Age of Izu-Bonin-Mariana arc basement. Earth and Planetary Science Letters, 481, 80-90. https://doi.org/10.1016/j.epsl.2017.10.023

Ishizuka, O., Kimura, J. I., Li, Y. B., Stern, R. J., Reagan, M. K., Taylor, R. N., et al. (2006). Early stages in the evolution of Izu-Bonin arc volcanism: New age, chemical, and isotopic constraints. Earth and Planetary Science Letters, 250(1-2), 385-401. https://doi.org/10.1016/j. epsl.2006.08.007

Ishizuka, O., Tani, K., Reagan, M. K., Kanayama, K., Umino, S., Harigane, Y., et al. (2011). The timescales of subduction initiation and subsequent evolution of an oceanic island arc. Earth and Planetary Science Letters, 306(3-4), 229-240. https://doi.org/10.1016/j. epsl.2011.04.006

Ito, G., McNutt, M., \& Gibson, R. (1995). Crustal structure of the Tuamotu Plateau, $15^{\circ}$ S, and implications for its origin. Journal of Geophysical Research, 100(B5), 8097-8114. https://doi.org/10.1029/95JB00071

Ivandic, M., Grevemeyer, I., Berhorst, A., Flueh, E., \& McIntosh, K. (2008). Impact of bending related faulting on the seismic properties of the incoming oceanic plate offshore of Nicaragua. Journal of Geophysical Research, 113, B05410. https://doi.org/10.1029/2007JB005291

Ivandic, M., Grevemeyer, I., Bialas, J., \& Peterson, J. C. (2010). Serpentinization in the trench-outer rise region offshore of Nicaragua: Constraints from seismic refraction and wide-angle data. Geophysical Journal International, 180, 1253-1264. https://doi:10.1111/j.1365246X.2009.04474.x

Karato, S., \& Jung, H. (1998). Water, partial melting and the origin of the seismic low velocity and high attenuation zone in the upper mantle. Earth and Planetary Science Letters, 157, 193-207. http://doi.org/10.1016/S0012-821X(98)00034-X

Kelley, K. A., Plank, T., Newman, S., Stolper, E. M., Grove, T. L., Parman, S., \& Hauri, E. H. (2010). Mantle melting as a function of water content beneath the Mariana Arc. Journal of Petrology, 51(8), 1711-1738. https://doi.org/10.1093/petrology/egq036

Kersting, A. B., Arculus, R. J., \& Gust, D. A. (1996). Lithospheric contributions to arc magmatism: Isotope variations along strike in volcanoes of Honshu. Japan. Science, 272(5267), 1464-1468. https://doi.org/10.1126/science.272.5267.1464

Kimura, J.-I., Hacker, B. R., van Keken, P. E., Kawabata, H., Yoshida, T., \& Stern, R. J. (2009). Arc basalt simulator version 2, a simulation for slab dehydration and fluid-fluxed mantle melting for arc basalts: Modeling scheme and application. Geochemistry Geophysics Geosystems, 10, Q09004. https://doi.org/10.1029/2008GC002217

Kimura, J.-I., \& Yoshida, T. (2006). Contributions of slab fluid, mantle wedge and crust to the origin of Quaternary lavas in the NE Japan arc. Journal of Petrology, 47(11), 2185-2232. https://doi.org/10.1093/petrology/egl041

Kodaira, S., Sato, T., Takahashi, N., Ito, A., Tamura, Y., Tatsumi, Y., \& Kaneda, Y. (2007). Seismological evidence for variable growth of crust along the Izu intraoceanic arc. Journal of Geophysical Research, 112, B05104. https://doi.org/10.1029/2006JB004593

Kodaira, S., Sato, T., Takahashi, N., Miura, S., Tamura, Y., Tatsumi, Y., \& Kaneda, Y. (2007). New seismological constraints on growth of continental crust in the Izu-Bonin intra-oceanic arc. Geology, 35(11), 1031-1034. https://doi.org/10.1130/G23901A.1

Kodaira, S., Sato, T., Takahashi, N., Yamashita, M., No, T., \& Kaneda, Y. (2008). Seismic imaging of a possible paleoarc in the Izu-Bonin intraoceanic arc and its implications for arc evolution processes. Geochemistry Geophysics Geosystems, 9, Q10X01. https://doi.org/ 10.1029/2008GC002073

Korenaga, J., Holbrook, W., Kent, G., Kelemen, P., Detrick, R., Larsen, H. C., et al. (2000). Crustal structure of the southeast Greenland margin from joint refraction and reflection seismic tomography. Journal of Geophysical Research, 105(B9), 21,591-21,614. https://doi. org/10.1029/2000JB900188

Manning, C. E. (1995). Phase-equilibrium controls on SiO2 metasomatism by aqueous fluid in subduction zones: Reaction at constant pressure and temperature. International Geology Review, 37(12), 1074-1093. https://doi.org/10.1080/00206819509465440

Martinez, F., Stern, R. J., Kelley, K. A., Ohara, Y., Sleeper, J. D., Ribeiro, J. M., \& Brounce, M. (2018). Diffuse extension of the southern Mariana margin. Journal of Geophysical Research: Solid Earth, 123, 892-916. https://doi.org/10.1002/2017JB014684

Mottl, M. J., Komor, S. C., Fryer, P., \& Moyer, C. L. (2003). Deep-slab fluids fuel extremophilic Archaea on a Mariana forearc serpentinite mud volcano: Ocean Drilling Program Leg 195. Geochemistry, Geophysics, Geosystems, 4(11), 9009. https://doi.org/10.1029/ 2003GC000588

Ohara, Y., \& Ishit, T. (1998). Peridotites from the southern Mariana forearc: Heterogeneous fluid supply in mantle wedge. Island Arc, 7(3), 541-558. https://doi.org/10.1111/j.1440-1738.1998.00209.x

Ohara, Y., Reagan, M. K., Fujikura, K., Watanabe, H., Michibayashi, K., Ishii, T., et al. (2012). A serpentinite-hosted ecosystem in the southern mariana forearc. Proceedings of the National Academy of Sciences, 109(8), 2831-2835. https://doi.org/10.1073/ pnas.1112005109

Okino, K., Kasuga, S., \& Ohara, Y. (1998). A new scenario of the Parece Vela Basin genesis. Marine Geophysical Researches, 20(1), 21-40. https://doi.org/10.1023/A:1004377422118

Okino, K., Shimakawa, Y., \& Nagaoka, S. (1994). Evolution of the Shikoku Basin. Earth Planets and Space, 46(6), 463-479. https://doi.org/ 10.5636/jgg.46.463

Peacock, S. M., Christensen, N. I., Bostock, M. G., \& Audet, P. (2011). High pore pressures and porosity at $35 \mathrm{~km}$ depth in the Cascadia subduction zone. Geology, 39(5), 471-474. https://doi.org/10.1130/G31649.1

Plank, T., \& Langmuir, C. H. (1998). The chemical composition of subducting sediment and its consequences for the crust and mantle. Chemical Geology, 145(3-4), 325-394. https://doi.org/10.1016/S0009-2541(97)00150-2

Ranero, C. R., Morgan, J. P., Mcintosh, K., \& Reichert, C. (2003). Bendingrelated faulting and mantle serpentinization at the middle America trench. Nature, 425(6956), 367-373. https://doi.org/10.1038/nature01961

Reymer, A., \& Schubert, G. (1984). Phanerozoic addition rates to the continental crust and crustal growth. Tectonics, 3(1), 63-77. https:// doi.org/10.1029/TC003i001p00063

Ribeiro, J. M., Stern, R. J., Martinez, F., Ishizuka, O., Merle, S. G., Kelley, K., et al. (2013). Geodynamic evolution of a forearc rift in the southernmost Mariana Arc. Island Arc, 22(4), 453-476. https://doi.org/10.1111/iar.12039

Schmidt, M. W., \& Poli, S. (1998). Experimentally based water budgets for dehydrating slabs and consequences for arc magma generation. Earth and Planetary Science Letters, 163(1-4), 361-379. https://doi.org/10.1016/S0012-821X(98)00142-3

Shillington, D. J. (2018). Water takes a deep dive into the Mariana Trench. Nature, 563(7731), 335-336. https://doi.org/10.1038/d41586-01807335-8

Shillington, D. J., Bécel, A., Nedimović, M. R., Kuehn, H., Webb, S. C., Abers, G. A., et al. (2015). Link between plate fabric, hydration and subduction zone seismicity in Alaska. Nature Geoscience, 8(12), 961-964. https://doi.org/10.1038/ngeo2586 
Stern, R. J., Fouch, M. J., \& Klemperer, S. L. (2003). An overview of the Izu-Bonin-Mariana subduction factory. Geophysical Monograph Series, 138, 175-222. https://doi.org/10.1029/138GM10

Suyehiro, K., Takahashi, N., Ariie, Y., Yokoi, Y., Hino, R., Shinohara, M., et al. (1996). Continental crust, crustal underplating, and low-Q upper mantle beneath an oceanic island arc. Science, 272(5260), 390-392. https://doi.org/10.1126/science.272.5260.390

Takahashi, N., Kodaira, S., Klemperer, S. L., Tatsumi, Y., Kaneda, Y., \& Suyehiro, K. (2007). Crustal structure and evolution of the Mariana intra-oceanic island arc. Geology, 35(3), 203-206. https://doi.org/10.1130/G23212A.1

Takahashi, N., Kodaira, S., Tatsumi, Y., Kaneda, Y., \& Suyehiro, K. (2008). Structure and growth of the Izu-Bonin-Mariana arc crust: 1. Seismic constraint on crust and mantle structure of the Mariana arc-back-arc system. Journal of Geophysical Research, 113, Q10X01. https://doi.org/10.1029/2007JB005120

Takahashi, N., Kodaira, S., Tatsumi, Y., Yamashita, M., Sato, T., Kaiho, Y., et al. (2009). Structural variations of arc crusts and rifted margins in the southern Izu-Ogasawara arc-back arc system. Geochemistry Geophysics Geosystems, 10, Q09X08. https://doi.org/10.1029/ 2008GC002146

Tatsumi, Y., Shukuno, H., Tani, K., Takahashi, N., Kodaira, S., \& Kogiso, T. (2008). Structure and growth of the Izu-Bonin-Mariana arc crust: 2. Role of crus-mantle transformation and the transparent Moho in arc crust evolution. Journal of Geophysical Research, 113, Q10X01. https://doi.org/10.1029/2007JB005121

Taylor, B. (1992). Rifting and the volcanic-tectonic evolution of the Izu-Bonin-Mariana arc. Proceedings of the Ocean Drilling Program, Scientific Results, 126, 627-651. http://www-odp.tamu.edu/publications/126_SR/VOLUME/CHAPTERS/sr126_42.pdf

Van Avendonk, H. J. A., Holbrook, W. S., Lizarralde, D., \& Denyer, P. (2011). Structure and serpentinization of the subducting Cocos plate offshore Nicaragua and Costa Rica. Geochemistry Geophysics Geosystems., 12, Q06009. https://doi.org/10.1029/2011GC003592

Wan, K., Xia, S., Cao, J., Sun, J., \& Xu, H. (2017). Deep seismic structure of the northeastern South China Sea: Origin of a high-velocity layer in the lower crust. Journal of Geophysical Research: Solid Earth, 122, 2831-2858. https://doi.org/10.1002/2016JB013481

Wessel, P., \& Smith, W. H. F. (1995). New version of the generic mapping tools. Eos, Transactions American Geophysical Union, 76(33), 329. https://doi.org/10.1029/95EO00198

Wheat, C. G., Fryer, P., Fisher, A. T., Hulme, S., Jannasch, H., Mottl, M. J., \& Becker, K. (2008). Borehole observations of fluid flow from south Chamorro seamount, an active serpentinite mud volcano in the Mariana forearc. Earth and Planetary Science Letters, 267(3-4), 401-409. https://doi.org/10.1016/j.epsl.2007.11.057

White, R. S., McKenzie, D., \& O'Nions, R. K. (1992). Oceanic crustal thickness from seismic measurements and rare earth element inversions. Journal of Geophysical Research, 97(B13), 19,683-19,715. https://doi.org/10.1029/92JB01749

Xia, S., Zhao, D., \& Qiu, X. (2008). Tomographic evidence for the subducting oceanic crust and forearc mantle serpentinization under Kyushu, Japan. Tectonophysics, 449(1-4), 85-96. https://doi.org/10.1016/j.tecto.2007.12.007

Yamazaki, T., \& Stern, B. (1997). Topography and magnetic vector anomalies in the Mariana Trough. JAMSTEC Journal Deep Sea Research, 13, 31-45. http://www.godac.jamstec.go.jp/catalog/data/doc_catalog/media/shinkai13_03.pdf

Zhang, F., Lin, J., \& Zhan, W. (2014). Variations in oceanic plate bending along the Mariana Trench. Earth and Planetary Science Letters, 401, 206-214. https://doi.org/10.1016/j.epsl.2014.05.032

Zhang, F., Lin, J., Zhou, Z., Yang, H., \& Zhan, W. (2018). Intra- and inter-trench variations in flexural bending of the Manila, Mariana and global trenches: Implications on plate weakening in controlling trench dynamics. Geophysical Journal International, 212(2), 1429-1449. https://doi.org/10.1093/gii/ggx488

Zhao, D., Hasegawa, A., \& Horiuchi, S. (1992). Tomographic imaging of $P$ and $S$ wave velocity structure beneath northeastern Japan. Journal of Geophysical Research, 97(B13), 19,909-19,928. https://doi.org/10.1029/92JB00603

Zhou, Z., \& Lin, J. (2018). Elasto-plastic deformation and plate weakening due to normal faulting in the subducting plate along the Mariana Trench. Tectonophysics, 734, 59-68. https://doi.org/10.1016/j.tecto.2018.04.008

Zhou, Z., Lin, J., Behn, M. D., \& Olive, J. A. (2015). Mechanism for normal faulting in the subducting plate at the Mariana Trench. Geophysical Research Letters, 42, 4309-4317. https://doi.org/10.1002/2015GL063917 